\title{
Working
}

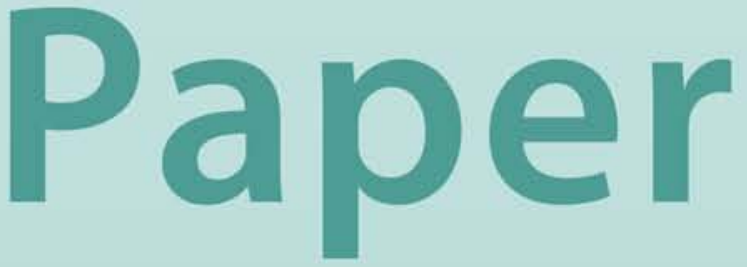




\title{
Selected Issues Concerning Monetary Policy and Institutional Design for Central Banks: A Review of Theories
}

\author{
Christian H. Beddies
}




\title{
IMF Working Paper
}

\author{
Monetary and Exchange Affairs Department
}

\section{Selected Issues Concerning Monetary Policy and Institutional Design for Central Banks: A Review of Theories}

\author{
Prepared by Christian H. Beddies ${ }^{1}$
}

Authorized for distribution by Arne B. Petersen

August 2000

\begin{abstract}
The views expressed in this Working Paper are those of the author(s) and do not necessarily represent those of the $\mathrm{MMF}$ or IMF policy. Working Papers describe research in progress by the author(s) and are published to elicit comments and to further debate.
\end{abstract}

In the past decades, much work has been geared toward solving the problem of time inconsistency in monetary policy and analyzing the coordination problem between fiscal and monetary policy. This paper provides a review of the theoretical background to these theories, while also focusing on their inherent problems. It concludes that while the literature makes a strong case for central bank independence, more work should be done in the area of determining the desirable degree of independence with a view to the interplay between fiscal and monetary policy.

JEL Classification Numbers: E3, E5, E6

Keywords: Monetary policy, time inconsistency, coordination, public finance

Author's E-Mail Address: cbeddies@imforg

${ }^{1}$ The author wishes to thank Richard Disney, Arne B. Petersen, Jaime Cardoso, Tonny Lybek, Luis I. Jacome H., and Abdourahmane Sarr for helpful comments and suggestions on earlier drafts of this paper, part of which was drawn from the author's Ph.D. dissertation. 
I. Introduction

II. The Time Inconsistency Problem ………...........................................................

A. Some solutions to the time inconsistency problem........................................

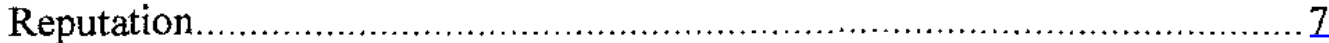

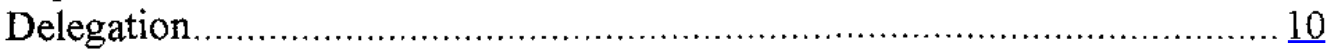

A multisector economy with partisanism ...............................................

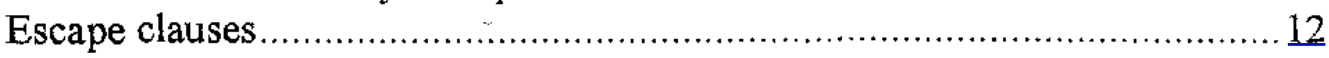

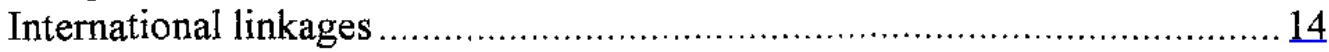

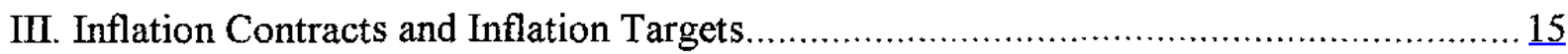

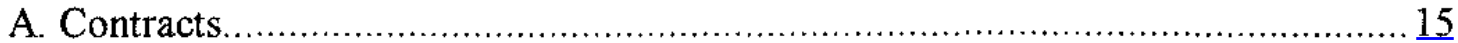

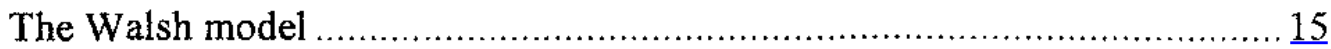

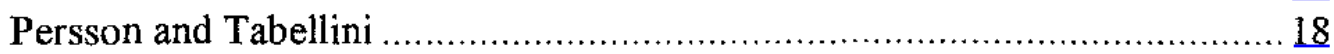

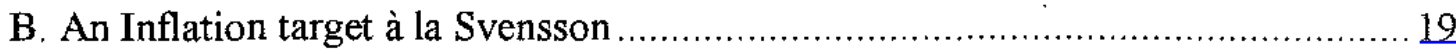

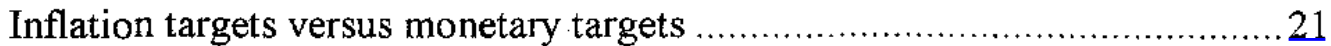

C. Problems with the contracting and the targeting approach ...............................2]

Principal agent or time inconsistency problem? ....................................2]

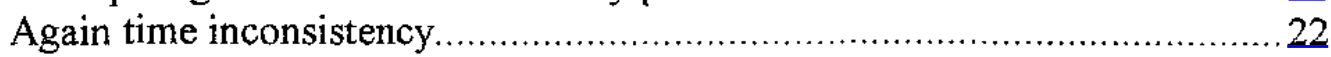

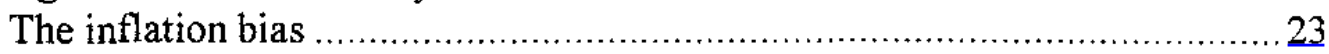

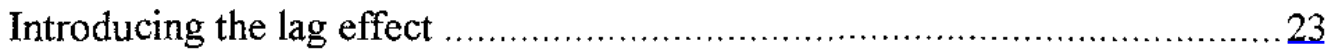

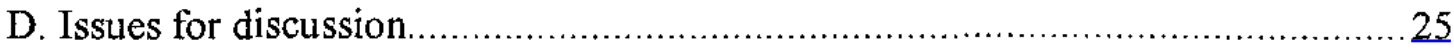

IV. The Coordination Problem in Fiscal and Monetary Policymaking …........................26

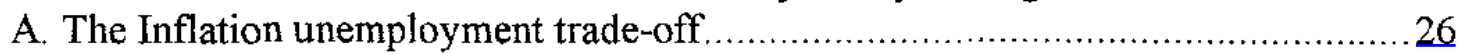

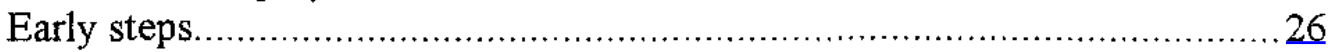

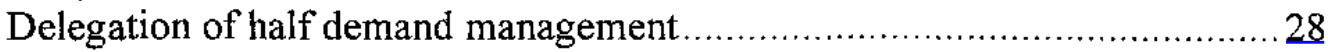

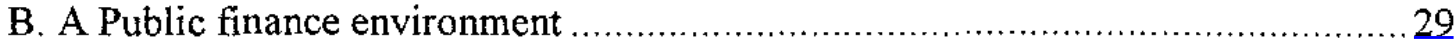

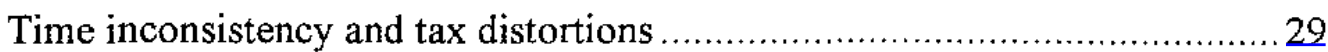

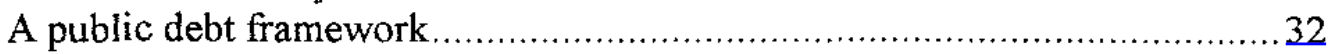

C. Links to the discussion of inflation contracts and targets .................................34

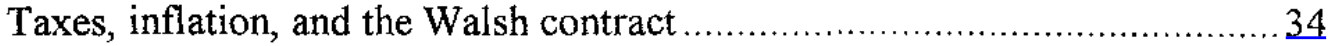

Public finances and inflation targets .......................................................34

The monetary policy implications and public debt..................................36

D. A general equilibrium approach-Monetary Union .......................................37

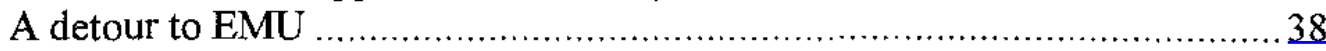

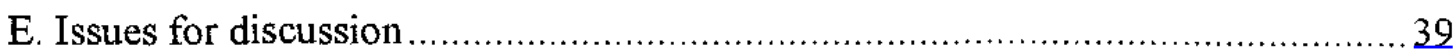

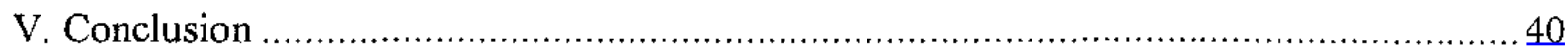

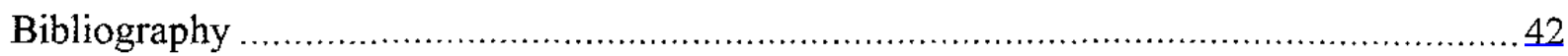




\section{INTRODUCTION}

When posing the question "Who should control the Money Supply", Thompson (1981) stated:

"Our optimal monetary authority: (I) has distributionaly neutral, politically independent, preferences; (2) erroneously believes that increases in the actual rate of inflation increase expected rates of inflation by nearly equal amounts; and (3) is both willing and able to respond to aggregative demand or supply shocks with monetary shocks before the former have significant, popularly abservable effects."

Even earlier, Milton Friedman (1962) asked whether the monetary authority should be an independent institution or not. He came up with his well known finding that instead of having an independent monetary institution, the central bank should follow a constitutionalyzed money growth rule, the famous k-percent rule. Since then, the literature on monetary policy, central banking and central bank independence has gained widespread attention and has been growing ever since. From a practical viewpoint, proper and well-defined national monetary policymaking became especially interesting after the final breakdown of the fixed exchange rate mechanism of Bretton Woods in $1973 .{ }^{3}$ Central Banks were now able to follow their own monetary policy goals, which was viewed especially important in the light of inflationary pressures due to the first oil price shock in 1973-74.

The literature in this field of interest can be divided into three strands. First, there is the wellknown time inconsistency discussion as well as some early suggestions for its solution. It dates back to the seminal work of Kydland and Prescott (1977) and has received much attention over the past decades. Among others, the papers by Barro and Gordon (1983a and 1983b), Canzoneri (1985), Rogoff (1985), and al Nowaihi and Levine (1994) should be mentioned. Second, there is a relatively new literature, building on this first theoretical foundation, on institutional design of monetary policy, which was initiated by Walsh (1995a) and extended upon Walsh's earlier work by Persson and Tabellini (1993). The key feature of these kinds of models is to provide the monetary authority with the appropriate incentive scheme in order to achieve the optimal policy and time consistent behavior. Within this line of research Svensson (1995) showed that under certain circumstances, the contractual approach à la Walsh can be mimicked by a suitable chosen inflation target. This route is especially interesting, since it has some practical relevance. Targeting inflation has become popular among some central banks, for example in New Zealand 1989, Canada 1991, Israel

${ }^{2}$ Thompson (1981), p. 360 .

${ }^{3}$ After the first Dollar Crises in 1971 the U.S. government suspended the agreement to change Dollar reserves into gold. Attempts to restore the fixed rate system finally failed in 1973 after the second Dollar crises. The main factor for this failure was the balance of payments deficit of the United States at this time. 
1991, and the United Kingdom 1992. ${ }^{4}$ Bernanke and Mishkin (1997) for example provide an excellent discussion about inflation targeting as a new framework for monetary policy. When viewed as a framework for conducting monetary policy and not as an inflexible rule, they conclude, the inflation targeting framework bears the advantage of more transparency and accountability in the process of monetary policy making. Finally there exists a large body of literature dealing specifically with the interaction of monetary and fiscal policies, both with respect to the often discussed Phillips trade-off and public debt, that is in a public finance setting. Some of the pioneers in this line of research have been Andersen and Schneider (1986), Alesina and Tabellini (1987), and Tabellini (1986 and 1988). Among others also Huang and Padilla (1995), and Beetsma and Bovenberg (1997a), who extended upon Alesina and Tabellini (1987), did some interesting work in this field.

The first two strands of the literature explicitly deal with aspects of optimal stabilization in the face of output shocks, without considering fiscal constraints and their implications for monetary policy. On the other hand the bulk of the literature on the interaction of monetary and fiscal policy, both with respect to the Phillips trade-off, as well as in a public finance framework ignores the presence of shocks. These issues are particularly interesting and important because central banks clearly do not operate in a political vacuum. The 1998 discussion about the presidency of the European Central Bank (ECB) clearly showed that central banks, whether in a common currency area like the European Monetary Union (EMU), or on a national level, cannot entirely separate themselves from the political process. The process of European monetary unification even strengthens this argument as sovereign states have given away an important policy instrument, namely monetary policy, which requires a thoughtful justification to the population of each individual country.

The empirical literature-which the paper will not discuss-mboth looks at the relationship between central bank independence and output variability and the potential linkage between deficits and monetary growth. Maybe the most striking empirical finding which relates to the theory of monetary policy, especially to Rogoff's conservative central banker, is the one by Alesina and Summers (1993). Empirical evidence for developed countries does not suggest the presence of a trade-off between credibility and flexibility. According to Alesina and Summers' (1993) findings, more independent central banks bring about a reduction in inflation and its variance without affecting the variability of output; this simply means that measures of central bank independence and output/unemployment variability are uncorrelated. ${ }^{5}$ Regarding a possible linkage between deficits and money growth, Joines

${ }^{4}$ This new field of interest and practical application was discussed and evaluated at a workshop, organized by CEPR and IGIER in November (1994) and summarized in the book "Inflation Targets", edited by L. Leiderman, and L. E. O. Svensson. The issue was also discussed at a conference of central banks, organized by the Bank of England in March 1995, also summarized in a book "Targeting Inflation", edited by A. Haldane.

${ }^{5}$ Also see Cukierman et al (1993). For developing countries there is no negative correlation between central bank independence and the mean as well as the variance of inflation (see 
(1985) for instance does not find such a relationship in the United States over the period of 1872-1983, apart from the war years. ${ }^{6}$ In an unpublished paper I find very similar results for the case of Germany. Favero and Spinelli (1996) find a weak long run relationship between money growth, deficits and inflation in Italy (between 1875-1994), only until 1975. The reason for this structural break in 1975 is that the Italian central bank started to gain more and more independence, finally refusing to buy unsold government bonds from the treasury from 1981 onwards (the so called divorce).

The purpose of this paper is to provide a review of the theoretical background to these theories also focusing on their inherent problems. For a long time, monetary policy making was looked at from the perspective of potential dynamic inconsistencies, with delegation as the most popular solution to the problem. The second building block of monetary policy analysis is how it interacts with fiscal policy. While the literature provides extensive background for each of these building blocks, less effort has been made in actually linking them. As a result, while the literature makes a strong case for central bank independence, more work should be done in the area of determining the desirable degree of independence, particularly with a view to fiscal and monetary policy interaction, taking account of stabilization issues within newer frameworks such as inflation targeting. In that regard the paper provides a different angle to the issue compared to--for example-Eijffinger and Hahn (1996), who focus more on the issue of central bank independence per se and to a lesser extent on the coordination problem of fiscal and monetary policy and the potential cooperation between the fiscal and the monetary authority.

The ideas presented in this paper can only be a selective choice from the large set of literature existing within this line of research. Also note that the first two streams ("building block 1") can be classified as alternative approaches in favor of an independent monetary authority, commonly known as central bank independence. ${ }^{7}$ The last stream, as mainly dealing with the

Cukierman (1992)). In an update of the Eijffinger and Haan (1996) survey, Berger, Haan, and Eijffinger (2000) survey more recent empirical findings according to which potential correlations crucially depend on the choice of the index used to capture central bank independence. Other factors such as the exchange regime and the financial sector's opposition against inflation are also shown to play an important role.

${ }^{6}$ For a comprehensive analysis of the monetary history of the United States (1867-1960) see Friedman and Schwartz (1963).

${ }^{7}$ Some authors argue that the term autonomy is preferred to the term independence, since autonomy entails operational freedom while independence indicates a lack of institutional constraints. However, the distinction between goal and instrument independence (Fischer 1995) specifies the concept of independence. Also see Eijffinger and Hahn (1996) who make the distinction between personnel, financial, and policy independence. 
coordination problem between monetary and fiscal policy, is to some extent related to some arguments against central bank independence, albeit with some exceptions. ${ }^{8}$

The paper is organized as follows. Section II will start with the well-known time inconsistency problem as well as the various early attempts to resolve it, such as reputation and delegation of monetary policy to a conservative central banker. Section III assesses the recent suggestions to solve the problem of dynamic inconsistency with the contracting and targeting approach, its benefits as well as its problems. Section IV summarizes the key literature on the coordination problem of monetary and fiscal policy. Most of this survey will be non-technical but in some cases, a few equations are used for easier illustration and reference will be made to the original source for details.

Section V concludes this paper and attempts to give some further ideas and suggestions relating to the models that are discussed.

\section{The Time Inconsistency Problem}

As long as decisions made by private agents are final when policymakers make their decisions, the ex post optimal policy differs from the ex ante optimal policy because policy choices no longer have an impact on private behavior. The result of this dilemma is that an announcement to stick to the ex ante optimal policy is not credible, since the policymaker has an incentive to deviate from the announcement in the optimization process. A seminal paper on the credibility problem concerning monetary policy was written by Kydland and Prescott (1977). It examines the inconsistency of optimal plans using standard control theory. The socially optimal policy in a game between a policymaker and rational private agents is not credible in their set-up and therefore not time consistent. Why is this the case? The reason is straightforward. Suppose the authority in charge of monetary policy announces a target of zero inflation in a standard Phillips curve environment. If the private sector took this announcement for granted, i.e., sets its expectation of inflation accordingly and hence enters into fixed wage contracts, the monetary authority has an incentive to deviate from the ex ante optimal policy of zero inflation. This is true if the wage contracts are fixed for a sufficiently long time horizon. However, as the public is assumed to act rationally and hence to know about the monetary authority's incentive problem, it will incorporate this information before entering into the wage contracts. The resulting equilibrium policy thus entails an inflationary bias. As a result control theory appears not to be the appropriate tool for dynamic economic planning as long as current decisions also depend upon expected future decisions and not only upon current and past policy decisions and upon the current state. Therefore, rather than discretionary policy, an implemented policy rule (for example, by legislation), preferably simple and easily understandable, so that a deviation from the rule becomes obvious, seems to be the solution to the problem.

\footnotetext{
${ }^{8}$ See for instance McCallum (1996) and Goodhart (1993b) for some critical remarks with respect to that issue.
} 
In that context Barro and Gordon (1983a) found that in a well-defined rational expectations framework this trade-off totally disappears because the private sector cannot be surprised by the government. Thus, if the policymaker acts in a discretionary manner rather than following a rule, equilibrium unemployment/output remains at its natural rate while inflation is positive. However no mechanism exists to implement an optimal policy rule for the above mentioned reasons. Barro and Gordon's main findings can be summarized as follows: (i) in equilibrium, rates of monetary growth and inflation are excessive; (ii) these rates depend on the slope of the Phillips curve, the natural rate of unemployment as well as on the weights the policymaker places on its objectives, as they affect the costs and benefits of inflation; and (iii) commitments to follow a policy rule would improve the situation. The question, which immediately arises in that context, is how can optimal policy decisions be implemented which are credible?

\section{A. Some solutions to the time inconsistency problem}

\section{Reputation}

As policymaking is not a one-shot process but rather an ongoing repeated interaction with the public, the concept of reputational equilibria involves giving a policymaker an incentive not to deviate from the optimal policy by making deviation costly to the policymaker. The intuition behind this story is the following. If policymaking is defined as a sequential process, an obvious intertemporal trade-off emerges. The current benefit of surprise inflation in terms of boosting output might well be outweighed by the future costs of higher expected inflation, resulting from the current expansionary policy. Thus, the appealing feature of the reputational approach is exactly this intertemporal linkage between current monetary decisions and future consequences of these decisions. ${ }^{9}$

Barro and Gordon (1983b) were the first to apply the concept of reputation to monetary policy. As there are no economic state variables in their set-up, the model can be thought of as a repeated infinite time horizon game. ${ }^{10}$ The policymaker now has to balance the short run gains of generating surprise inflation against the cost of higher expected inflation generated by the private sector in the future. The problem of this model, however, is that there are many possible equilibria resulting in the well-known multiplicity problem. The reason for this dilemma is the existence of an infinite number of punishment strategies (Friedman-type

\footnotetext{
${ }^{9}$ See Currie and Levine (1993) for an extensive exploration of these issues. For a discussion regarding pros and cons with respect to the reputation building approach see Rogoff (1987). Some generalizations of simple macro models with incomplete information have been analyzed by Driffill (1989).
}

${ }^{10}$ The key assumption of this approach is that information is complete. 
trigger strategies) ${ }^{11}$ which could be adopted. Thus, the model lacks the predictive power expected from a model of monetary policy and inflation. As a result, a second problem emerges. Each possible equilibrium requires that all agents coordinate when the policymaker deviates from the expected rate of inflation. In addition, revisions of expectations take place immediately after observing a deviation. Thus, the expected rate of inflation is discontinuous. This means that if the private sector observes actual inflation being different from its expectations in period $t-1$, it will revise its expectations for period $t$. In other words the repeated game is one of complete information and the government takes a certain monetary policy action in equilibrium because it believes it will be punished if it cheats. According to Cripps (1996, p. 522) this use of the term reputation is never found in the game theoretic literature. Hence the appropriate usage would be in an incomplete information framework as, e.g., analyzed by Kreps and Wilson (1982) and Milgrom and Roberts (1982).

Subsequent elaboration of the reputation approach thus focused on alternative informational structures. Canconeri (1985) for example considered a monetary policy model with private information. This necessarily involves a monitoring problem as shocks to inflation are assumed to be neither observable to the private sector ex ante nor ex post. Backus and Driffill (1985) and Barro (1986) particularly focus on incomplete information models of reputation, i.e., in the spirit of Cripps (1996). Barro (1986) for example used the well-known KrepsWilson (1982) reputation game (Selten's (1978) chain-store paradox). ${ }^{12}$ The advantage of this framework is that it does not rely on the assumption of an infinite time horizon. As is straightforward from the of Kreps-Wilson (1982) analysis the introduction of uncertainty about the policymakers' types, i.e., introducing incomplete information, ensures the existence of unique reputational equilibria in a finite time horizon. The private sector is now able to learn about the policymaker's true type by updating its beliefs according to Bayes rule.

Vickers (1986) instead stressed the problem of signaling a policymaker's true type to the incompletely informed private sector. In his model a tough policymaker (tough on fighting inflation) might have to go through undesired contractionary policies in order to separate himself from the weak type.

\footnotetext{
${ }^{11}$ Friedman type trigger strategies simply require that starting from cooperation the noncooperative strategy is played after a deviation of the opponent was observed. See Friedman (1971) and (1977).
}

${ }^{12}$ The idea of the "chain-store paradox" is the following: In a game concerning a chain-store, with a monopolistic incumbent and a potential entrant, Selten (1978) showed that with a finite time horizon the entrant will always enter the market as the incumbent has no incentive to fight market entry in the last period (using backward induction). This so called paradox was resolved by Kreps and Wilson (1982) by introducing uncertainty about the incumbent's type. The incumbent is now able to build up a reputation for being tough, i.e., always fighting potential entrants and hence deterring market entry. 
A paper by al Nowaihi and Levine (1994) extended the Barro and Gordon (1983b) framework in an interesting way. The main concern of the authors is to address the problems of the original Barro and Gordon (1983b) reputation framework, namely the multiplicity of equilibria, the coordination problem and what the authors call chisel-prone credibility problem (meaning that a sufficiently small deviation from the optimal policy might not trigger punishment). The problem with pure trigger strategies is that they are not credible because they require a once and for all non-cooperative behavior after one deviation of the opponent. Within a long time horizon this sort of punishment might hurt the punishing player more than not punishing a deviation at all. Hence the private sector has to choose the minimum punishment period that is required to support the most favorable outcome from the private sector's point of view, i.e., supports the lowest possible rate of inflation in a credible fashion. The resulting coordination problem is solved either by assuming a game between successive monetary authorities with an atomistic private sector or by assuming centralized wage bargaining where a union represents the private agents to coordinate them, forms expectations and punishes the policymaker for observed deviations from the optimal policy. The credibility problem inherent in this game, namely the credible punishment mentioned above is resolved by what the authors call the chisel-proof credibility condition. This simply means that the punishment period of the trigger strategies is endogenized. In other words, by chisel-proof credibility the authors understand the requirement that retaliation be better than acquiescing to any deviation and not just the optimal deviation represented by conducting the discretionary policy. ${ }^{13}$ The idea is to solve for an upper bound of the punishment period up to which punishment for deviation is credible (note that the analysis is off the equilibrium path). This setting is particularly interesting and useful as it addresses and solves an inherent problem in the application of repeated games (with complete information) of monetary policy. It emphasizes the solution to the credibility problem with respect to the punishing party and not only with respect to the policymaker.

Furthermore, Waller (1995) identifies two problems with the reputation approach in the context of central bank policy. ${ }^{14}$ As this approach tends to focus on the central banker rather than the central bank as an institution, there appears uncertainty and variability in the policy setting process. This is because central bankers turn over and do not perform their policies forever. Furthermore, if the central bank's incentives are wrong, resulting in an inflationary bias, it seems to be more appropriate to change the institutional framework, rather than letting the private sector "solve" the problem via punishment strategies. In the light of this critique one might argue that the reputational approach as outlined above is lacking an institutional component. Recently this problem has been addressed-for example, Jensen (1997) and al Nowaihi and Levine (1996) - in the sense that the institutional component of

${ }^{13}$ See al Nowaihi and Levine (1994), p. 356.

${ }^{14}$ See Waller (1995), p. 5-6. 
central banking, e.g., via the Walsh (1995a) contract, is merged with the reputational component of appointing central bankers. ${ }^{15}$

\section{Delegation}

So far the discussion has not distinguished between the policymaker or policymaking institution and the government or society as a whole. The question arising in this context is whether delegation can solve the credibility problem of monetary policy. An often-quoted paper in this context is that by Rogoff (1985). Appointing a "conservative" central banker, that is a person with a low time preference and higher preference for price stability relative to employment targets makes society better off. On the other hand if the central banker only cares about inflation, shocks to the economy would not be stabilized, which is costly in this model. To get a better intuition, assume the following simple Rogoff-type model: ${ }^{16}$

Suppose that the social loss function is a quadratic function of two objectives:

$$
L_{t}=\frac{1}{2}\left\{\pi_{t}^{2}+\lambda\left(y_{t}-y^{*}\right)^{2}\right\}
$$

where $\pi_{t}$ denotes the actual rate of inflation, $y_{t}$ denotes output, $y^{*}$ is target output and $\lambda$ is the policymaker's weight, placed on the output deviation term. This is standard in the literature.

Without loss of generality and for illustrative purposes output is given by a simple Lucastype supply function:

$$
y_{t}=\pi_{t}-\pi_{t}^{e}+\varepsilon_{t}
$$

where $\pi_{t}$ is actual inflation, $\pi_{t}{ }^{e}$ denotes expected inflation conditional on information up to and including period t- 1 and $\varepsilon_{t}$ is an i.i.d. distributed supply shock with zero mean and variance $\sigma_{\varepsilon}^{2}$.

Given (2) and (3) below it is straightforward to see that the "natural" or long run equilibrium of the expected output level is normalized at zero. By combining the assumption that the natural level of output is zero on average and the assumption that $y^{*}>0$, one can capture the idea that distortions in the labor market, such as income taxes, prevent the natural level of output from being at its desired level $\mathrm{y}^{*}$. In other words $\mathrm{y}^{*}$ would be the long run equilibrium output level in the absence of any distortions. I will come back to this issue further below.

The private sector's rational expectations can be expressed in the following equation:

\footnotetext{
${ }^{15}$ See section III below.

${ }^{16}$ Alesina and Gatti (1995) simplify the Rogoff model in the same way.
} 
$E_{t-1}\left(\pi_{t}\right)=\pi_{t}^{e}$

The first order condition resulting from minimizing (1) with respect to the rate of inflation (the instrument) subject to (2) and taking rational expectations of the private sector (3) as given, can be solved for inflation and output (time subscripts are dropped):

$$
\begin{aligned}
& \pi=\lambda y^{*}-\frac{\lambda}{1+\lambda} \varepsilon \\
& \pi^{e}=\lambda y^{*} \\
& y=\frac{1}{1+\lambda} \varepsilon
\end{aligned}
$$

The first term in (4) is the so called inflation bias, which occurs because the policymaker does not take into account the impact of his or her actions on the expectations of the private sector (see (5)). The second term in (4) captures the extent to which the rate of inflation should respond to an aggregate supply shock. Similarly, (6) is the output response to the supply shock. From (4), (5) and (6) it follows that:

$$
\begin{aligned}
& E(\pi)=\lambda y^{*} \\
& E(y)=0 \\
& \operatorname{Var}(\pi)=\left[\frac{\lambda}{1+\lambda}\right]^{2} \sigma_{\varepsilon}^{2} \\
& \operatorname{Var}(y)=\left[\frac{1}{1+\lambda}\right]^{2} \sigma_{\varepsilon}^{2}
\end{aligned}
$$

Rogoff (1985) showed that the inflationary bias can be reduced by delegating monetary policy to an agent, who is more conservative than society as a whole such as a central banker who cares less about output relative to inflation. In the present set-up this means that the weight, $\lambda^{\mathrm{c}}$ say, the agent places on the output deviation term in (1) is smaller than $\lambda$, i.e., $\lambda^{\mathrm{c}}<$ $\lambda$. But this reduction comes at the cost of increased output variability, as can easily be verified by inspection of the output variance in (7). Obviously there is a trade-off involved here, namely the trade-off between credibility and flexibility. ${ }^{17}$ The issue of credibility versus flexibility in a public finance setting will be discussed in section IV.

Concerning the ranking of the different types of equilibria, there are two viable possibilities. Rogoff referred consistently to the equilibrium corresponding to an optimal rule (commitment) as second best because a first best would require removing the distortions

${ }^{17}$ In contrast to Rogoff's theoretical finding, empirical evidence, described by Alesina and Summers (1993) does not suggest the existence of such a trade-off (in developed countries). 
responsible for the actual level of output being below its natural level. The equilibrium with the conservative central banker would then be third best, while the discretionary equilibrium is referred to as fourth best. Alternatively one can describe the commitment equilibrium as the first best (policy), the intermediate equilibria as second best and the discretionary equilibrium as third best. ${ }^{18}$

\section{A multisector economy with partisanism}

Waller (1992) focuses on a variant of the Rogoff (1985) model in a multisector framework. Assuming that the economy consists of a "classical" and a "nonclassical" sector with fully flexible / inflexible wages and prices respectively and that labor supply is immobile between sectors, while goods are treated as mobile between sectors, to allow for spill-over effects, his main results can be summarized as follows. Due to wage rigidities in the nonclassical sector, the output variance will be higher than in the classical sector, although preferences in both sectors are assumed to be the same. Consequently this results in a disagreement between sectors regarding the conservativeness of a potential central banker to be appointed, as the nonclassical sector has to suffer more in terms of a higher output variance than the classical sector starting from the discretionary equilibrium. If two different political parties represent the two sectors, the process of appointing a conservative central banker will be subject to partisan influences.

\section{Escape clauses}

Lohmann (1992) elaborated an extension of the Rogoff model to stress the trade-off between credibility and flexibility in central banking. ${ }^{19}$ In her model the central bank's principal has an ex ante choice, not only of which agent to appoint, but also of the ex post cost of "getting rid" of the agent. The result is an equilibrium policy which looks like a rule with an escape clause: under normal circumstances the central bank follows a non-inflationary rule. The monetary authority answers with discretion when the gain of stabilization is particularly high.

The intuition behind this idea is as follows. The central bank acts independently, either credibly committed to a rule or just more conservative than the rest of the society, within an interval for the aggregate supply shock and will be overridden by the government if the

${ }^{18}$ See, for example, Svensson (1995), p.1.

${ }^{19}$ Also see the contribution by Herrendorf and Lockwood (1996) for an exploration of this issue. In an international context, Currie, Levine, and Pearlman (1996) focus on the delegation issue. They conclude that it is the exchange rate externality that results in an inefficient Nash equilibrium to the Rogoff type delegation game. 
Figure 1: Conservative Central Bankers and Escape Clauses

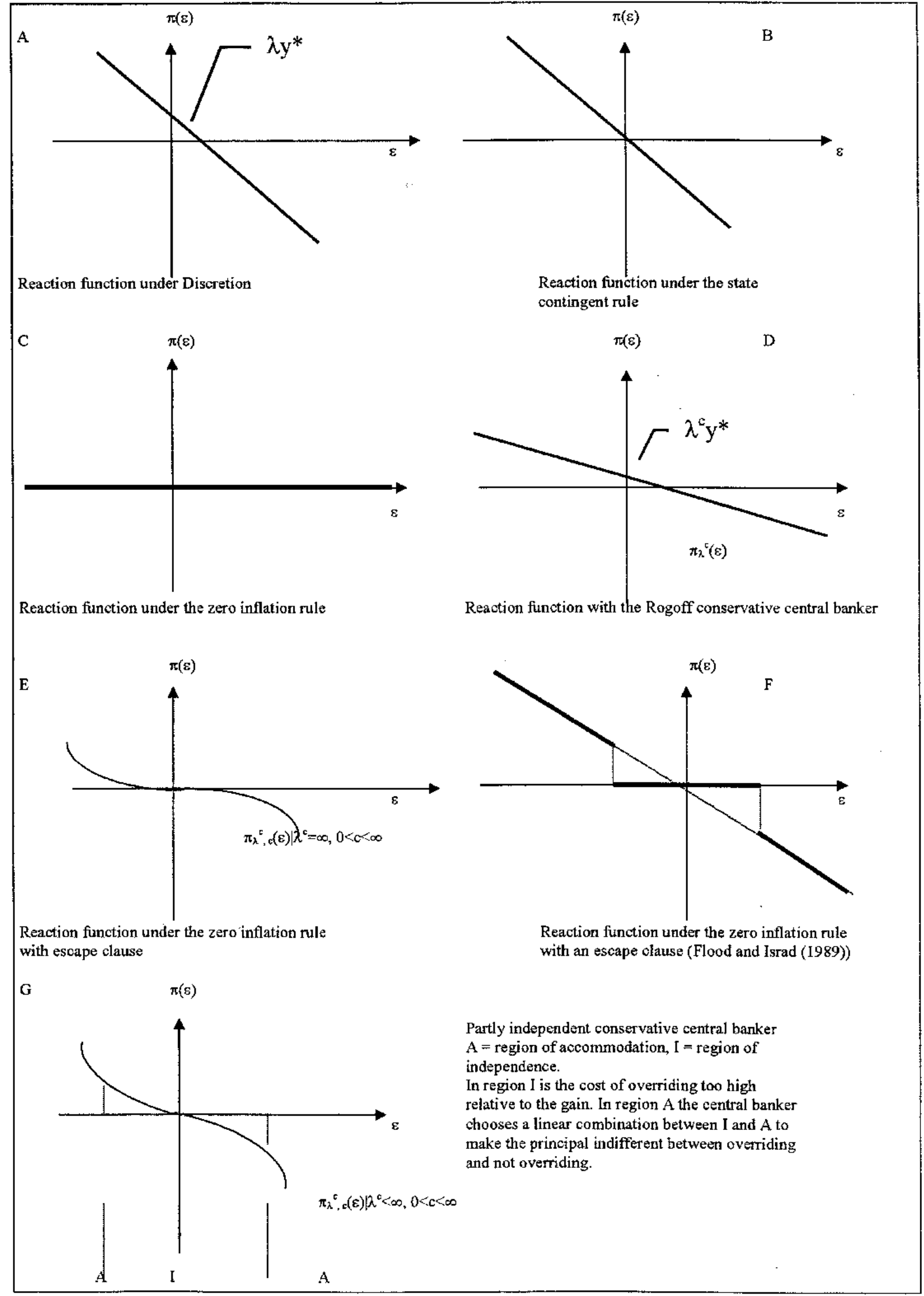

Source: Lohmann 1992, p. 276-281, modified for the notation here. 
observed supply shock falls outside that interval. The width of this interval necessarily depends on the cost of overriding the monetary authority. Consequently, a higher cost is connected with a lower incentive to interfere with the central bank's decision.

The approaches in the previous sections are illustrated in Figure $1 \mathrm{~A}-\mathrm{G}$. Let $\pi$ be the rate of inflation, $\varepsilon$ be the supply shock, $\mathrm{c}$ be the cost of overriding the central banker, $\lambda$ be the weight a normal central banker (as society) places on the output deviation term and $\lambda^{c}$ be the weight a conservative central banker places on the output deviation term (as before). The equilibrium will necessarily induce the monetary authority to choose an inflation rate which makes the government just indifferent between overriding the central bank's decision and accepting it (see, Figure $1 \mathrm{G}$ ). Figure $1 \mathrm{~B}$ simply captures the situation where the central bank follows a fully state contingent rule. Necessarily there is no inflationary bias (the reaction function intersects the origin) and shocks to the economy are fully accommodated. Comparing graph $\mathrm{A}$ and $\mathrm{D}$ shows how a more conservative central banker modeled through the lower relative weight on output, $\lambda^{\mathrm{c}}$, responds to shocks compared to a central banker who has the same preferences over output and inflation as society has. Obviously the inflationary bias under discretion is higher than with the conservative central banker, but on the other hand Figure $1 \mathrm{D}$ shows that conservativeness results in less stabilization of shocks, i.e., the reaction function is flatter. As easily verified from Figure $1 \mathrm{C}$, a zero inflation rule results in no shock stabilization at all. Figure $1 \mathrm{E}$ and $\mathrm{F}$ contrast the situation of the zero inflation rule (an infinitely conservative central banker) with an escape clause depending on the costs of overriding the central bank's decision, $c$, and the zero inflation rule with escape clause but without overriding costs.

\section{International linkages}

Canconeri et al (1995) compare the relatively modern inflation-targeting regime with the ERM. It was generally accepted that prior to the exchange rate crises in 1992 and 1993, the credibility in terms of inflation performance of some European countries was thought to derive from the ERM as well as from the independence of the Bundesbank. ${ }^{20}$ The reason why this was thought to work is simply that fixing the exchange rate to a low inflation currency serves to import credibility. But fixing the exchange rate to a low inflation currency also means that the foreign inflation rate will be imported. The crucial point here is the following. The shocks by which the foreign sector of the economy is hit will (partly) be accommodated by the foreign monetary policy, i.e., the foreign central bank follows its own objectives and needs. Therefore foreign problems will be transferred to the home country and problems in the home country are not fully accommodated by the foreign monetary policy. ${ }^{21}$ The choice

\footnotetext{
${ }^{20}$ Canconeri et al (1995), p. 1
}

${ }^{21}$ This necessarily depends on similarities and differences of the economies under inspection. Very different countries are hit by shocks in different ways with different impact, which makes the problem more severe. On the other hand this is less problematic if the home and 
among the different arrangements depends on a number of considerations. Canconeri et al (1995) conclude that targeting inflation is preferable if i) political pressures, which distort the monetary authorities policy are not too big in the first place; ii) the foreign central bank is conducting a very different monetary policy; and iii) the supply shocks are primarily of regional not international magnitude. ${ }^{22}$

\section{INFLATION CONTRACTS AND INFLATION TARGETS}

The models presented so far have basically evaluated monetary policy in the usual framework of linear quadratic loss functions commonly known in macroeconomic analysis. But there exists a powerful tool in microeconomic theory intended to resolve incentive problems of the type that arise in delegation of responsibilities, namely the modern literature on contracts, regulation and principal-agent relations. These tools were first used by Walsh in his (1995a) publication.

\section{A. Contracts}

\section{The Walsh model}

The basic idea of Walsh's (1995a) approach is the use of an optimal contract mechanism to eliminate the inflationary bias mentioned above. The incentive to deviate from the optimal policy by creating surprise inflation is eliminated as the transfer to the policymaker, specified in the contract, adds a cost component to this sort of deviation. This transfer has only to be contingent on observable variables, like the growth rate of the money supply, the inflation rate etc. The signal of a disturbance to the economy is assumed to be the private information of the monetary authority. This does not change the outcome, as the transfer is only contingent on observable variables. ${ }^{2324}$ So the central bank will choose the optimal policy and the inflationary bias of discretionary monetary policy can be eliminated while leaving the agent free to respond with discretion to the observed, private information, signal. To see this more explicitly, suppose the following simplified version of Walsh's model:

the foreign economy are quite similar and hence shocks are more like an international rather than a national problem.

${ }^{22}$ For a discussion of the ERM and EMU, see, e.g., Goodhart (1993a).

${ }^{23}$ A key result in Walsh's paper is that the central bank contract provides the right incentives. Hence it can solve the signal extraction problems faced by the private sector and is thereby able to remove the well known inflationary bias, while leaving discretion to respond optimally to aggregate shocks.

${ }^{24}$ Svensson (1995) showed that the same optimal outcome, specified in the "Walsh contract" can be achieved by defining a suitable inflation target, equal to the negative of the inflation bias (see below). 
Let the loss function be as defined as earlier:

$$
L_{t}=\frac{1}{2}\left\{\pi_{t}^{2}+\lambda\left(y_{t}-y^{*}\right)^{2}\right\}
$$

Output is given as before:

$y_{t}=\pi_{t}-\pi_{t}^{e}+\varepsilon_{t}$

The informational structure supposes that the monetary authority observes a signal $\theta=\varepsilon+\phi$ (where $\phi$ is a measurement error uncorrelated with the supply shock with zero mean and variance $\sigma_{\phi}{ }^{2}$ ) concerning the aggregate supply shock $\varepsilon$ (with zero mean and variance $\sigma_{\varepsilon}^{2}$ ) and sets inflation based on this knowledge. ${ }^{25}$ The signal $\theta$ is assumed to be the private information of the central bank, hence its expectation conditional on the signal is given as $E_{\theta}(\varepsilon)=\left[\sigma_{\varepsilon}{ }^{2} /\left(\sigma_{\varepsilon}{ }^{2}+\sigma_{\phi}{ }^{2}\right)\right] \theta \equiv s \theta$, with $s \leq 1{ }^{26}$ As before, $y^{*}>0$ captures distortions in the labor market and/or in the tax system and hence is above the expected natural level $E(y)=0$, which ensures that the monetary authority has an incentive to engage in surprise inflation. Walsh (1995a) assumes a positive natural rate of output (in the absence of any supply shocks or unanticipated inflation), $\mathrm{y}^{\mathrm{c}}$, and denotes the distortion by $\mathrm{k} \equiv \mathrm{y}^{*}-\mathrm{y}^{\mathrm{c}}>0$. In the present simplified set-up I shall simply assume $\mathrm{y}^{*}>0$.

The private sector's rational expectations are still given by:

$$
E_{t-1}\left(\pi_{t}\right)=\pi_{t}^{e}
$$

Suppose now that the principal of the central bank (in the Walsh model this is the government) can chose a transfer payment, conditional on observed inflation, ${ }^{27}$ to the central banker such that the central banker, to whom monetary policy is delegated, maximizes the following utility function:

${ }^{25}$ In contrast to this, Walsh uses the money supply as an instrument of the monetary authority but the simplification here does not change any qualitative result.

${ }^{26} \mathrm{~s}$ is equal to 1 , if $\theta$ is a rational forecast of the aggregate supply shock $\varepsilon$. The central bank forms expectations conditional on the signal, $\theta$, i.e., conditional on $\varepsilon+\phi$. This means that the distribution of $\varepsilon$ conditional on $\theta$ is $\varepsilon+\phi=\theta$, if the distribution of $\varepsilon$ given $\varepsilon+\phi$ is normal.

Therefore $\mathrm{E}_{\theta}(\varepsilon)=\mathrm{E}(\varepsilon)+\left[\sigma_{\varepsilon}{ }^{2} /\left(\sigma_{\varepsilon}{ }^{2}+\sigma_{\phi}{ }^{2}\right)\right](\varepsilon+\phi)=\left[\sigma_{\varepsilon}{ }^{2} /\left(\sigma_{\varepsilon}{ }^{2}+\sigma_{\phi}{ }^{2}\right)\right] \theta \equiv \mathrm{s} \theta$. Hence $\mathrm{s}=1$ if and only if $\sigma_{\phi}^{2}=0$, i.e., $\theta$ is a rational forecast of the aggregate supply shock $\varepsilon$.

${ }^{27}$ The principal can not verify the signal $\theta$ ex post, which means that contracts which are contingent on any realization of $\theta$ are ruled out. This does not seem to be a problem, as fully state contingent contracts are not feasible and more or less impossible to enforce. 
$U_{t}=t-L_{t}$

We could think of the transfer payment $t$ in several ways: It could be a wage payment or just be thought of as prestige, which the central banker earns for good performance and which increases the probability of a second term or a highly ranked job afterwards. In other words, the central banker is assumed to care about his transfer $t$ and the social loss, which is generated through inflation and output variability. Technically the principal has to design a transfer scheme $t$ that induces the central banker to chose the optimal policy $\pi_{t}=\pi_{t}(\theta)$, while fulfilling his participation constraint $E\left(t-\mathrm{L}_{t}\right) \geq \mathrm{U}_{0}$, where $\mathrm{U}_{0}$ is the central banker's reservation utility, for simplicity assumed to be zero. Furthermore, to implement the optimal policy, the central banker's incentive compatibility constraint must be fulfilled, that is $\pi_{\mathfrak{t}}(\theta)$ must maximize $E_{\theta}\left(t\left(\pi_{t}\right)-L_{t}\right)$ for all $\theta$.

Walsh has shown that the optimal policy can be implemented by simply setting the transfer function (in this simplified example, dropping time subscripts): ${ }^{28}$

$$
t(\pi)=t_{0}-\lambda y^{*} \pi
$$

It is easy to verify that providing the central banker with this incentive contract removes the inflationary bias $\lambda y^{*}$ as stated in (4) and implements the optimal policy: ${ }^{29}$

$\pi(\theta)=-\frac{\lambda}{1+\lambda} s \theta$

Another interesting case analyzed by Walsh is where the central bank does not share the same preferences over inflation and output fluctuations. If the agent who implements monetary policy only cares about the transfer income received from the government, the contract based on ex post variables as output and inflation is not unique. One might think that the problem can be solved by paying the agent a fixed amount to "just follow instructions" (dead contract). But as the signal over the shock to the economy is assumed to be private information of the agent, the principal would not be able to verify whether the instructions had in fact been followed; a complete set of contingent instructions cannot possibly be provided. The solution to that problem is a performance based incentive mechanism, which must depend on output and inflation.

${ }^{28}$ Remember that the specified loss function (8) assumes a target rate of inflation of zero. A positive target could be captured by subtracting, $\pi^{*}$ say, from $\pi$ in (8) and square the deviation. Necessarily (12) would become $t(\pi)=t_{0}-\lambda y^{*}\left(\pi-\pi^{*}\right)$.

${ }^{29}$ Note that this differs from the stabilization term (second term) in (4) because the central bank forms expectations conditional on the signal $\theta$. 


\section{Persson and Tabellini}

Persson and Tabellini (1993) follow a similar line of reasoning, inspired by an earlier version of Walsh's (1995a) paper. Accepting that incentive problems may be the major complication to price stability, they ask which institutions may help to resolve these problems. Two directions are of interest in this context. First, the legislative approach to create by law a very independent central bank and second the targeting approach. The latter imposes an explicit inflation target for monetary policy and makes the central bank explicitly accountable to its principals for the success in meeting the target. This approach is more or less followed by New Zealand (1989) and Canada (1991). The basic normative question asked throughout Persson and Tabellini's paper is what are the features of an optimal contract from the point of view of society's ex ante preferences: a question of institution design, as the authors call it. As in the paper by Walsh (1995a), the inflationary bias of discretionary monetary policymaking can be eliminated by a simple contract that imposes a linear penalty for inflation on the central bank. This result is shown to be robust to imperfect monitoring by the private sector. If some information is non-verifiable and therefore non-contractual, policy announcements by the central bank become very important. In this case the optimal contract leads to a truthful revelation by the central bank about the stochastic shock to the economy and the ex ante optimal policy will be implemented. If the central bank's political principals have private interests, that is to say they do not fully represent the preferences of the society, e.g., through partisan or electoral incentives, only incomplete contracts can be written. In this situation there arises a trade-off between information and incentives, i.e., legislative control and targeting. If the central bank controls inflation only indirectly and imperfectly, the incentive contract (which then is an incomplete one) has the property that the agent's payoff is not based on the principal's objective. ${ }^{30}$

Some general insights of this approach are that writing incomplete contracts may still not require a loss of stabilization policies. Furthermore the approach concerns the desirability of inflation targets compared to intermediate targets. Persson and Tabellini (1993) state:

\footnotetext{
"Why do we observe central banks rarely held accountable for the rate of inflation? ...It may be that a commitment to a more readily observable nominal variable, such as a monetary aggregate or the exchange rate, is easier to enforce. A second possible answer is that central bankers would not like to be held accountable for something they do not control tightly, and hence are more liable to miss rather often."
}

\footnotetext{
${ }^{30}$ This was analyzed more detailed by Baker (1992).

${ }^{31}$ Persson and Tabellini (1993), p. 77
} 
Monetary policy announcements, if transparent and clear, can serve as a reference point against which to judge central bank behavior now and in the future. Transparent policy making seems especially important since it can serve as a substitute for reputation. ${ }^{32}$

\section{B. An inflation target à la Svensson}

In his (1995) contribution, Svensson showed that a suitable chosen inflation target can mimic the optimal outcome induced by a Walsh type contract. Suppose the social loss function (1) is modified in the following way; i.e., assuming a non-zero socially desirable rate of inflation:

$$
L_{t}=\frac{1}{2}\left\{\left(\pi_{t}-\pi^{*}\right)^{2}+\lambda\left(y_{t}-y^{*}\right)^{2}\right\}
$$

It is easy to verify that discretionary policy results in (dropping time subscripts and assuming output as given in (9)):

$$
\begin{aligned}
& \pi=\pi^{*}+\lambda y^{*}-\frac{\lambda}{1+\lambda} \varepsilon \\
& \pi^{e}=\pi^{*}+\lambda y^{*} \\
& y=\frac{1}{1+\lambda} \varepsilon
\end{aligned}
$$

Clearly, the optimal solution would be:

$$
\begin{aligned}
& \pi=\pi^{*}-\frac{\lambda}{1+\lambda} \varepsilon \\
& \pi^{e}=\pi^{*}
\end{aligned}
$$

while (17) remains the same.

By constructing an appropriate transfer scheme, namely $t(\pi)=t_{0}-\lambda y^{*}\left(\pi-\pi^{*}\right)$, and letting the central banker maximize utility $\mathrm{U}_{\mathrm{t}}=\mathrm{t}-\mathrm{L}_{\mathrm{t}}$, as before, we would obtain the optimal solution, characterized through (18), (19) and (17).

To explain the Svensson approach, suppose now that the central bank's period loss function is given by: ${ }^{33}$

\footnotetext{
${ }^{32}$ See for example Briault, Haldane and King (1995).

${ }^{33}$ See Svensson (1995) p. 10 ff. for details.
} 
$L_{t}^{b}=\frac{1}{2}\left\{\left(\pi_{t}-\pi^{b}\right)^{2}+\lambda\left(y_{t}-y^{b}\right)^{2}\right\}$

where the b superscript denotes the bank's target, which may differ from the socially desirable target rate. Clearly in this set-up the discretionary equilibrium in terms of inflation (15) becomes:

$\pi=\pi^{b}+\lambda y^{b}-\frac{\lambda}{1+\lambda} \varepsilon$

Suppose further that for simplicity $\mathrm{y}^{*}=\mathrm{y}^{\mathrm{b}}$. One can now rewrite the central bank's loss function to get:

$$
\begin{aligned}
& L_{t}^{b}=\frac{1}{2}\left\{\left[\left(\pi_{t}-\pi^{*}\right)+\left(\pi^{*}-\pi^{b}\right)\right]^{2}+\lambda\left(y_{t}-y^{*}\right)^{2}\right\}= \\
& \frac{1}{2}\left\{\left(\pi_{t}-\pi^{*}\right)^{2}+\lambda\left(y_{t}-y^{*}\right)^{2}+2\left(\pi_{t}-\pi^{*}\right)\left(\pi^{*}-\pi^{b}\right)+\left(\pi^{*}-\pi^{b}\right)^{2}\right\} \\
& L_{t}^{b}=L_{t}+\left(\pi_{t}-\pi^{*}\right)\left(\pi^{*}-\pi^{b}\right)+\frac{1}{2}\left(\pi^{*}-\pi^{b}\right)^{2}
\end{aligned}
$$

The difference between the social loss function $L_{t}$ and the central bank's loss function $L_{t}^{b}$ is given by a term that is linear in $\pi_{\mathrm{t}}$ (the second term in (22)) and a constant (the third term in (22)). Thus, by choosing $\pi^{\mathrm{b}}$ to fulfil $\pi^{*}-\pi^{\mathrm{b}}=\lambda \mathrm{y}^{*}$ or $\pi^{\mathrm{b}}=\pi^{*}-\lambda \mathrm{y}^{*}$ the inflation target and the Walsh contract are equivalent. For a zero optimal (socially desirable inflation rate) this implies that the imposed target is negative. In the example here this is equivalent to imposing the transfer scheme $t(\pi)=t_{0}-\lambda y^{*}\left(\pi-\pi^{*}\right)$, where the constant here coincides with the third term in (22). ${ }^{34}$

Svensson also shows that with the assumption of persistent output, an optimal state contingent inflation target can remove the average as well as the state contingent part of the inflation bias, but it leaves the variance of inflation still too high in contrast to an optimal state contingent inflation contract. Basically the Svensson approach is a mathematical trick of rewriting the central banks loss function (20) as shown in (22). The key problem with this approach is to find a rationale for imposing a negative inflation target, if the optimal rate of

\footnotetext{
${ }^{34}$ Remember that in the contracting case, the policymaker was assumed to maximize $U_{t}=t$ $L_{t}$, while with the inflation target he or she was minimising the period loss function $L_{t}^{b}$.
} 
inflation is zero. Even for a positive optimal rate of inflation, Svensson's approach implies that the inflation target has to be below society's inflation target (the optimal rate) ${ }^{35}$

\section{Inflation targets versus monetary targets}

Cukierman (1995) showed that the choice of a monetary target involves a trade off between visibility and controllability. Targeting a monetary instrument such as the monetary base, because it is easier to control, has a reduced impact on expectations of the private sector, as it is less visible. On the other hand inflation targets are more visible and therefore have a higher impact on the public sector's expectations. However, the rate of inflation is harder to control by the central bank. In Cukierman's model the public assigns a certain probability that the policymaker in charge of monetary policy is dependable, i.e., capable to commit himself to a certain policy. If the policymaker is targeting the monetary base, which he can perfectly control, the target is only given attention by a fraction of the public. In contrast to that an inflation target attains full attention by the public, but as mentioned above is not that easy to control. Announcing monetary targets then works as a signaling device, where the dependable policymaker tries to separate himself from the weak policymaker. Cukierman's main results are that the relative advantage of base targets increases with their visibility. A perfect reputation of being dependable makes inflation targeting always preferable as the public gives it wider attention. The relative advantage of base targeting increases with a decrease of controllability over inflation. Hence the easier it is for the weak policymaker to mimic a tough type the more advantageous are monetary base targets because of their visibility. $^{36}$

\section{Problems with the contracting and the targeting approach}

\section{Principal agent or time inconsistency problem?}

The key problem with the discussion so far is that providing the central bank with the appropriate incentive scheme, either via the contract or via the inflation target, does actually not resolve the time inconsistency problem; it merely reallocates it as pointed out by McCallum (1995, p. 210) ${ }^{37}$ However, this unfortunate outcome looks different if it were up to society to implement an inflation contract for the central bank. Waller (1995) argues that the time inconsistency problem and the principal agent problem are not the same thing and this has important repercussions for renegotiation. If the principal (society) has the right

\footnotetext{
${ }^{35}$ Recall that the inflation target of the central bank has to be chosen such that $\pi^{b}=\pi^{*}-\lambda y$. A similar critique is brought forward by Beetsma and Jensen (1997), who extend the contracting and the targeting approach by allowing for uncertain central banker preferences.

${ }^{36}$ See Cukierman (1995), p. 205 for details.

${ }^{37}$ Additionally see McCallum (1996).
} 
preferences (e.g., no output target which is above the natural rate), which would guarantee the optimal policy outcome, renegotiation is not an issue. The reason is that society does not want to be fooled by the policymaker and reacts accordingly. However, we then have to ask, why should society have preferences that involve a temptation for creating surprise inflation without any benefits? Waller (1995) states: ${ }^{38}$

"But if the performance contract generates the socially optimal outcome regardless of whether society and the central banker have the same output targets, why is it important to classify the problem as a time inconsistency problem, rather than a principal-agent problem?"

This implies that society would not have a reason to renegotiate the inflation contract.

\section{Again time inconsistency}

With the government as the framer of the contract things are different: Why should the government act in a time consistent manner and not try to renegotiate the contract when unemployment is higher than desired by the government? ${ }^{39}$ From the analysis above we know that in absence of a pre-commitment technology the government would suffer from exactly the same incentive problem as the central bank would do without the inflation contract. Therefore al Nowaihi and Levine (1996) followed an interesting approach and actually resolve the dynamic inconsistency problem on the side of the central bank by using Walsh-type contracts in combination with reputational forces as analyzed by Barro (1986) to resolve the time inconsistency problem on the side of the government. ${ }^{40}$ The key feature of their model is that a Walsh-type central bank contract is not renegotiation proof and therefore has no credibility as a commitment device. Allowing for reputational aspects on the side of the government in an infinite horizon game, which means that governments are committed to a non-partisan monetary policy or that successive governments are perfectly correlated in their objectives ensures that the government never renegotiates the Walsh contract. In a finite horizon set-up this result does not hold, as at least at the end of the period of office renegotiation occurs. Both results naturally depend on the parameters of the model such as the discount rate etc. Therefore a first best solution is only possible if successive governments cooperate or if reputation could be passed over to successive governments. As each government has only a finite life and political programs and incentives usually differ, at least over time, this is a quite strong assumption.

${ }^{38}$ Waller (1995), p. 11

${ }^{39}$ Also see Canzoneri et al (1995).

${ }^{40}$ See al Nowaihi and Levine (1996), al Nowaihi and Levine (1994) and Herrendorf (1996). 


\section{The inflation bias}

Briault, Haldane and King (1995) mention three further problems with the Walsh contract. The simplicity of the contract solution crucially depends on the non-state-contingency of the inflation bias in the simplistic Barro-Gordon analysis. This means that if the inflation-bias becomes shock dependent, e.g., due to some interest rate targets in the loss function of the central bank as in Canzoneri et al (1995), a simple linear inflation contract can only remove the expected part of the inflationary bias. Except New Zealand, where the governor of the central bank can be dismissed for bad inflation performance, none of the countries which more or less employ performance contracts define explicit penalties in the case of missing the imposed targets. And finally, as most of the targeting procedures in practice have a quadratic (symmetric) nature, one might ask in which way a central bank benefits from undershooting its targets. $^{41}$

\section{Introducing the lag effect}

Although not much emphasized in the literature, it is common sense that monetary policy operates with relatively long lags. Once accepting this fact, the theoretical literature on resolving the time inconsistency problem of monetary policy becomes inconsistent itself. Goodhart and Huang (1995) state:

"If monetary instruments operate with a lag, than a rational public will observe them, (they can hardly fail to notice interest rate changes), and adjust their expectations accordingly. Hence the public cannot be fooled, and the time inconsistency problem argument vanishes. " 42

This is in contrast to the usual assumption that private sector wage contracts are fixed for a longer time than monetary policy needs to take its effects. As the standard set-up normally uses a Lucas type surprise supply function, ${ }^{43}$ whenever there is a lag in the operating of monetary instruments implies that wage and/or price contracts can be reviewed according to the latest monetary action. In such a setting the monetary authority is unable to fool anyone by creating surprise inflation, which means that there won't be an inflationary bias, nor can it know the value of future shocks. Thus $\mathrm{E}\left(\varepsilon_{\mathrm{t}+1}\right)=0$ and the monetary authority is unable to smooth shocks (due to the lag). Goodhart and Huang (1995) suggest that the monetary authority could simply follow Friedman's proposed k-percent rule, so as to make inflation equal to zero.

\footnotetext{
${ }^{41}$ For details see Briault, Haldane and King (1995).

${ }^{42}$ Goodhart and Huang (1995) p. 2.

${ }^{43}$ The Lucas supply function implies that all wages and prices are fully flexible.
} 
Again to see these implications more specifically, especially in the light of the contracting approach, let me set out this approach more formally:

Let the loss function be defined as before:

$L_{t}=\frac{1}{2}\left\{\pi_{t}^{2}+\lambda\left(y_{t}-y^{*}\right)^{2}\right\}$

Also as before the Lucas supply function is:

$y_{t}=\pi_{t}-\pi_{t}^{e}+\varepsilon_{t}$

Monetary policy is now assumed to operate with long lags, thus, the informational structure changes as follows:

$E_{t-1}\left(\pi_{t-1}\right)=\pi_{t-1}^{e}=\pi_{t-1}$

This simply means that the private sector fully anticipates and reacts to the actions of the monetary authority before the actions take effect. Suppose now that the central bank maximizes a utility function as in the simplified Walsh model (the signal is left out in order to simplify the analysis). That is to say, the central bank maximizes $U_{t}=t-L_{t}$, with $t(\pi)=t_{0}$ $\lambda y^{*} \pi_{t}$, i.e., $:^{44}$

$$
\begin{aligned}
& U_{t}=t_{0}-\lambda y^{*} \pi_{t}-\frac{1}{2}\left\{\pi_{t}^{2}+\lambda\left(y_{t}-y^{*}\right)^{2}\right\}= \\
& =t_{0}-\lambda y^{*} \pi_{t-1}-\frac{1}{2}\left\{\pi_{t-1}^{2}+\lambda\left(\pi_{t-1}-\pi_{t-1}^{e}+\varepsilon-y^{*}\right)^{2}=\right. \\
& =t_{0}-\lambda y^{*} \pi_{t-1}-\frac{1}{2}\left\{\pi_{t-1}^{2}+\lambda\left(\varepsilon-y^{*}\right)^{2}\right\}
\end{aligned}
$$

Due to the lag and the resulting informational structure this optimization problem is a trivial one and the first order condition with respect to inflation for a maximum is given by (dropping time subscripts):

$-\lambda y^{*}-\pi=0$

${ }^{44}$ The notation after the first equality symbol assumes a forward looking central banker. As monetary policy operates with lags, policy has no effects on current period utility and a myopic central banker could choose an arbitrary policy action. See Goodhart and Huang (1995) for details, who demonstrate this issue in a more sophisticated manner, with the interest rate as the instrument. 
If there were not an incentive problem in the first place, i.e., the contract would not be necessary, therefore $\mathrm{t}=0=>\mathrm{U}=-\mathrm{L}$, the central banker would set inflation equal to zero in each period which is simply following a k-percent rule a la Friedman. The striking result here is that imposing an inflation contract results in a deflationary bias (the first term in (27)) because there is no time inconsistency problem in the first place. This bias becomes larger if the central banker is less conservative, i.e., the higher is $\lambda$ and also if the monetary authority aims for higher output $y^{*}$. In such a situation the Walsh contract does more bad than good because it tries to correct an incentive problem which does not exist.

\section{Issues for discussion}

The last section focused on the contracting approach as a means to resolve the credibility problem. The key literature on this topic as mentioned above is the modern one of regulation, contracts and principal-agent relations, or broadly speaking, of mechanism design. This yields a powerful microeconomic tool on which macroeconomic analysis can be based, namely the construction of incentive schemes for monetary policymaking. However, introducing the assumption that monetary policy operates with sufficiently long lags, longer than the period for which wage contracts are fixed, implies that the contracting approach breaks down. As we have also seen, the Svensson approach requires that the principals of the central bank impose an inflation target that is below the socially optimal one or even a strictly negative inflation target, if the socially desirable rate of inflation is assumed to be zero. In practice this seems to be not feasible. How could one think of imposing a negative target rate for inflation? Would this be credible at all?

The only practical example for using approximately this sort of set-up in the real world is the New Zealand Reserve Bank Act of $1989 .{ }^{45}$ There, the only objective for monetary policy is to achieve and maintain price stability, in contrast with earlier objectives, which in addition to price stability also included growth, full employment and balance of payments objectives. The contract between the government and the Reserve Bank of New Zealand includes an agreement on publishing specific targets for the implementation of monetary policy. These need not necessarily be in terms of inflation targets (they are in fact), but they should aim at achieving price stability. More and more central banks tend to announce monetary policy targets. Canada first announced an inflation target in 1991, a longer term goal of monetary policy and the inflation targets since 1993; the central bank of Sweden since 1993 etc.; in Europe mainly after the exchange rate crises of September 1992. In this respect, some interesting questions arise.

\footnotetext{
${ }^{45}$ Approximately because the New Zealand Reserve Bank Act of 1989 allows for an adjustment with respect to the inflation target. This differentiates the Act from mimicking an optimal central bank contract, as the government might be tempted to change targets (at least) once some wage contracts are fixed. For an evaluation of the New Zealand Reserve Bank Act see Walsh (1995b).
} 
Who should write the contract or implement the target inflation rate? As mentioned earlier, a government imposed contract or inflation target might merely reallocate the problem of dynamic inconsistency. Furthermore, the government might have a strong incentive to distort the central bank's stabilization effort when imposing the contract or the inflation target. This might be due to private objectives or partisanism. Waller and Walsh (1996) set up a model along those lines and find that if central bank independence comes along "with a reduction in partisan influences, output variability can be negatively correlated with central bank independence"

\section{The CoOrdination Problem in Fiscal and Monetary Policymaking}

Having talked about the various problems of monetary policy and central banking in the first part of this paper, the task now is to examine the problems and their solutions regarding the coordination of monetary and fiscal policies. ${ }^{47}$

It is well known that a coordination problem requires the presence of two more or less independent authorities, conducting monetary and fiscal policy. With decentralized policymaking, where both authorities have their own objectives and their own preferences about how to reach those objectives one has to determine concepts to characterize the outcome of an interaction between these policies.

\section{A. The inflation unemployment trade-off}

\section{Early steps}

A natural question which arises in a setting of decentralized policymaking is as follows. Does there exist a trade-off between unemployment and inflation if a government deals with an independent central bank and where the two independent agents, the government and the central bank, have different and conflicting objectives (output/unemployment and inflation) $?^{48}$ Andersen and Schneider (1986) focus their attention on this problem.

"In classical economic policy analysis it is commonly assumed that the choice of fiscal and monetary policy is the outcome of a cooperative political process. ${ }^{49}$

${ }^{46}$ Waller and Walsh (1996), p. 1140.

${ }^{47}$ Also see Laurens and de la Piedra (1998) for a discussion on the coordination of monetary and fiscal policy.

${ }^{48} \mathrm{It}$ is not necessary to model the private sector explicitly if it is assumed that the central bank is keeping in mind its interests by setting an inflation target.

49 Andersen and Schneider (1986), p. 169. 
In contrast to the framework provided in the Andersen and Schneider (1986) paper, the "classical" policy analysis assumes that the central bank is in the same subordinate position as any other department of the government (e.g., Great Britain until May 1997 and France until 1994). In such circumstances, we would expect that the political process yields a coordinated result using fiscal and monetary instruments. ${ }^{50}$ This seems to be plausible as only one authority with only one objective function tries to find the optimal policy mix modeled in a game against the private sector.

In the Andersen-Schneider study the policy interaction is described as a game between the agents where possible actions are determined by the rules of the game. ${ }^{51}$ If the two agents, the fiscal authority and monetary authority, set their policies independently, it is clear that different preferences and therefore different weights attached to the targets (inflation and output) result in conflicting objectives. Furthermore coordination problems arise, as a characteristic feature of strategic decision situations. ${ }^{52}$ The authors explicitly model the decision situation of the fiscal authority and the monetary authority as a non-cooperative game under alternative institutional arrangements (the simultaneous Nash game and the sequential Stackelberg game) and under different macroeconomic frameworks (Keynesian and New Classical). Their main results can be summarized as follows: (i) in a pure Keynesian framework, uncoordinated fiscal and monetary policy results in inefficiencies, both in the Nash and the Stackelberg game (with the government as the leader), and cooperation would make both agents better off. More specifically fiscal policy is too expansionary, while monetary policy is too contractionary, compared to any cooperative solution; (ii) in the Stackelberg game, when the monetary authority only cares about inflation, they obtain a cooperative solution; and (iii) in a pure New Classical framework there does not exist a Nash equilibrium, nor a Stackelberg equilibrium. The result of such an interaction is that the player with the higher inflationary preferences rules the game.

Consider Figure 2 for a better illustration of what is happening in this model where the Nash equilibrium is given by the intersection of the two reaction functions (point D). ${ }^{53}$ Given the government chooses $g^{\prime}$ the optimal response of the central bank is $m$ '. But now $g$ ' is no longer an optimal response of the fiscal authority and she chooses g'. In point D these revisions of decisions come to an end and one obtains a Nash equilibrium. One can also see immediately that the Nash and the Stackelberg solution are inefficient, point D and E respectively, as they are not located on the Pareto frontier $\mathrm{AB}$.

${ }^{50}$ Andersen and Schneider (1986), p. $169 \mathrm{ff}$.

${ }^{51}$ See Friedman, 1991, p. 3.

${ }^{52}$ It is also important to note that in such a situation a cooperative outcome should not be expected as long as the time horizons of the government and the central bank are different.

${ }^{53}$ Andersen and Schneider 1986, p. 179. 
The situation where the central bank is the Stackelberg leader with respect to the government is not analyzed by Andersen and Schneider and thus not depicted in Figure 2.

Figure 2: Results of the Policy Game in the Cooperative and the Non-Cooperative Case

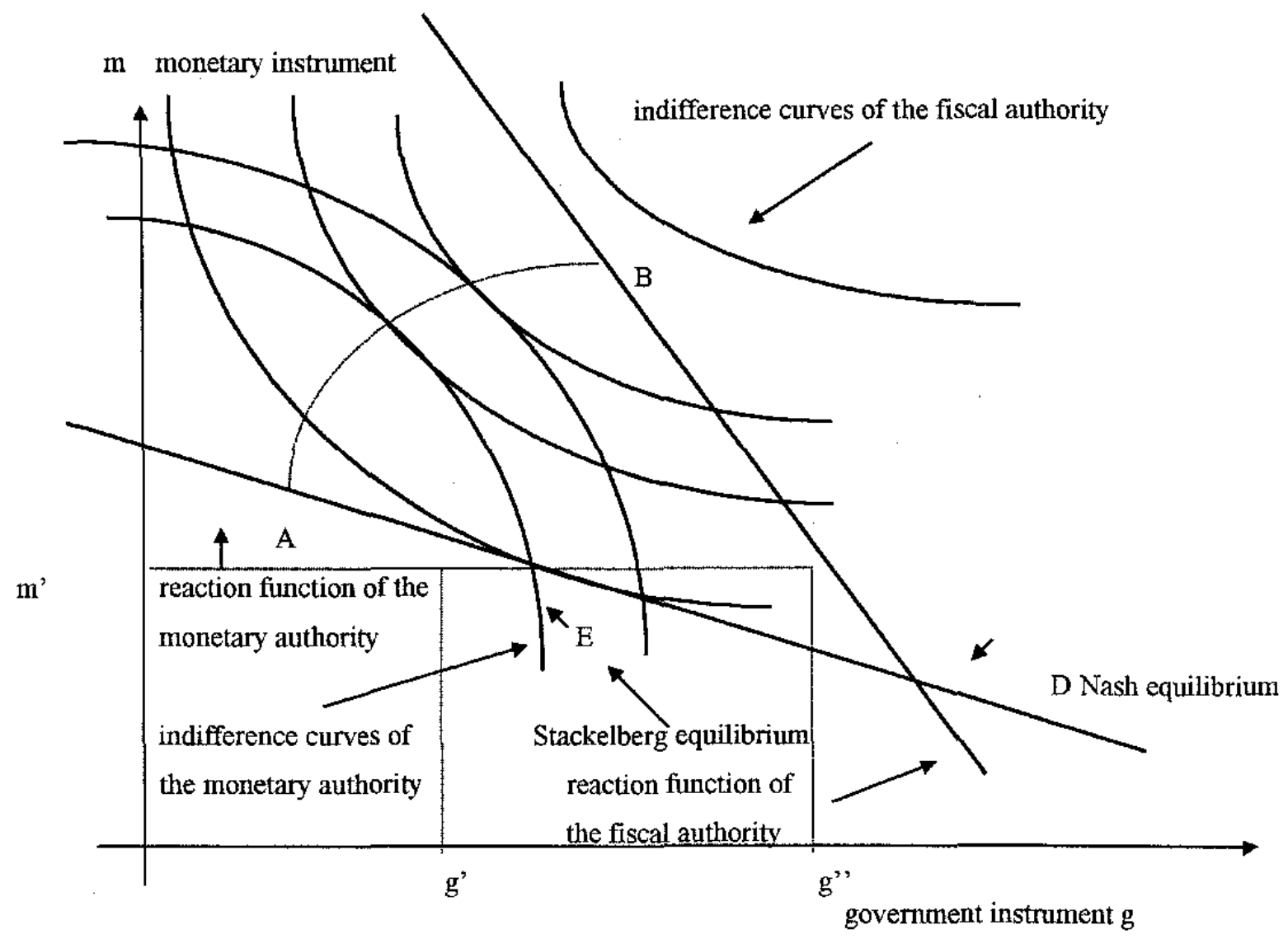

It is very important to note that the private sector is not modeled explicitly in this framework and therefore the inefficiency of the Nash solution occurs only from the point of view of the two authorities in charge. The key problem of the model is that aggregate supply is totally ignored here. When the fiscal authority is choosing the instrument, whatever this might be, it is unclear how this transmits to the private sector's behavior. An important question that also arises in that context, is the following: If fiscal policy is too expansionary in the noncooperative game, how is this policy financed in the light of low inflation? The model of Rankin (1995) gets around the problem of ignoring aggregate supply and shall be briefly discussed in the next paragraph.

\section{Delegation of half demand management}

In contrast to the above model, the private sector is modeled explicitly in this contribution. The basic model consists of an IS equation, a LM equation, and the usual Lucas type supply function (without considering supply shocks). The government, in charge of fiscal policy, is assumed to care about inflation, output and the interest rate with the commonly-used 
quadratic loss function. The central bank is assumed to care only about inflation. From the assumptions so far, it is clear that the central bank always gets its way as it has only one objective. The public sector's task is to choose the expected price level such as that it is equal to the actual price level, but moves first. Hence the public sector determines the position of the AS (aggregate supply) curve and then the central bank and the government choose their conditional output targets subject to the AS curve. ${ }^{54}$ The main findings of the paper can be summarized as follows. As the central bank only cares about inflation, delegation ensures that the central bank wins the battle. There is no inflation and no raise in output.

Unfortunately this comes at the cost of a higher interest rate as the central bank fights the expansionary ambitions of the government. If there is no delegation, the government can raise output at the cost of increased inflation. But as the private sector reoptimizes, i.e., adjusts its expectations, the equilibrium long run level of output will be at its natural rate. In the case where the central bank acts as a Stackelberg leader, the Nash outcome prevails. The reason for this is obvious. The central bank is assumed to care only about inflation. Necessarily the iso loss-curves of the central bank are vertical lines in the i-y (interest rateoutput) space; hence the Nash- and the Stackelberg solution are identical. In contrast to this, if the government acts as the Stackelberg leader, the central bank wins the battle but this time at a point where there is no inflation, no rise in output and low interest rates. Clearly this mimics the optimal solution in this framework. Summing up, delegation might induce a higher social loss as it is connected with higher interest rates.

This might explain why Germany experienced high interest rates in the early nineties after reunification.

"The 1990 reunification of East and West was the signal for the German government to
increase its spending very substantially, in order to assist the East German economy.
This put upward pressure on German inflation, which the Bundesbank countered by
tightening monetary policy. The result was a battle for control of aggregate demand,
with monetary contraction fighting fiscal expansion. In this battle the main damage was
suffered by the German interest rate, which both players' actions contributed to forcing
up. There has been much discussion of the recessionary impact on other countries in the
ERM at the time and of the destructive impact on the ERM itself,...",5.5

\section{B. A public finance environment}

\section{Time inconsistency and tax distortions}

So far the existence of the budgetary constraints which a government faces when engaging in fiscal policies have not been considered explicitly. The model of Alesina and Tabellini

\footnotetext{
${ }^{54}$ Naturally, the central banks output target has to be the natural level of output.

${ }^{55}$ Rankin (1995), p. 1.
} 
(1987) provides an analysis of rules and discretion within an uncoordinated monetary and fiscal policy setting.

"The time inconsistency of optimal monetary policy is due to the effects of tax distortions. Thus the issue of how to improve upon the time-consistent suboptimal monetary policy is related to that of the coordination of monetary and fiscal policy. " 56

Basically their model consists of three players. The private sector is represented by a trade union, minimizing deviations of the real wage from a positive target $v$. The government is in charge of fiscal policy, i.e., choosing an appropriate tax rate, and finally the central bank, in charge of monetary policy, chooses the appropriate rate of inflation. The two authorities are assumed to have preferences over inflation, output and public spending, where the weights placed on these objectives may or may not be equal. The time inconsistency problem in this model is generated through the lack of a non-distortionary fiscal instrument, which results in a reduction of economic activity and hence forces output below its natural level. Total revenue of the firms is taxed at rate $\tau$. Hence the aggregate supply function can be shown to satisfy: ${ }^{57}$

$y_{t}=\alpha\left(\pi_{t}-\pi_{t}^{e}-\tau_{t}-v\right)$, where $\alpha>0$

Ignoring public debt and denoting by $g$ the ratio of public expenditures over output, the authors show that the budget constraint of the government can be written as:

$g_{t}=\tau_{t}+\pi_{t}$

The authorities' loss functions are defined over inflation, output and public spending. Let the superscript $\mathrm{M}$ denote monetary authority (central bank) and the superscript $\mathrm{F}$ denote fiscal authority, i.e., the government. Then the loss functions are defined as:

$$
\begin{aligned}
& L^{M}=\frac{1}{2} \sum_{t=0}^{T} \beta^{t}\left[\pi_{t}^{2}+\mu_{1} y_{t}^{2}+\mu_{2}\left(g_{t}-\bar{g}\right)^{2}\right] \\
& \mu_{1}>0, \mu_{2} \geq 0,0<\beta<1, \bar{g}>0 \\
& L^{F}=\frac{1}{2} \Sigma_{t=0}^{T} \theta^{t}\left[\pi_{t}^{2}+\delta_{1} y_{t}^{2}+\delta_{2}\left(g_{t}-\bar{g}\right)^{2}\right] \\
& \delta_{1}>0, \delta_{2} \geq 0,0<\theta<1, \bar{g}>0
\end{aligned}
$$

\footnotetext{
${ }^{56}$ Alesina and Tabellini (1987), p. 619.

${ }^{57}$ The notation here is slightly changed, compared to the original Alesina and Tabellini (1987) model in order to be consistent with the notation of this paper. As this model is nonstochastic, there is no aggregate supply disturbance.
} 
The parameters $\beta$ and $\theta$ represent the two authorities' discount rates, $\mu_{\mathrm{i}}$ and $\delta_{\mathrm{i}}$ denote the weights the policymakers place on output and public spending, relative to inflation. Additionally $\pi_{\mathrm{t}}, \mathrm{y}_{\mathrm{t}}$, and $\mathrm{g}_{\mathrm{t}}$ represent inflation, output and public spending respectively. It is assumed that the positive public spending targets in (30) and (31) are the same. The key feature of this model is as follows. The strategic behavior of the involved parties arises due to the disagreement of how to achieve optimal financing of public spending. A positive real wage target of the trade union produces downward pressure on output. Furthermore positive spending has to be financed at least partly through taxes according to (29), which results in an additional downward pressure on output according to (28). Hence both authorities would like to create some surprise inflation in order to raise output towards its target, which is assumed to be zero here. ${ }^{58}$ In the discretionary setting the three players act in a Nash fashion, where everybody optimizes taking the decision of the others as given. Alesina and Tabellini show that the resulting equilibrium is characterized by the following conditions (where $\mathrm{D}$ stands for discretion):

$$
\begin{aligned}
& \left(\bar{g}-g^{D}\right)=\frac{\alpha^{2} \delta_{1}(v+\bar{g})}{\left[\alpha^{2} \delta_{1}\left(1+\mu_{2}\right)+\delta_{2}\left(1+\alpha^{2} \mu_{1}\right)\right]}>0 \\
& y^{D}=-\frac{\delta_{2}}{\alpha \delta_{1}}\left(\bar{g}-g^{D}\right)<0 \\
& \pi^{D}=\frac{\mu_{1} \delta_{2}+\mu_{2} \delta_{1}}{\delta_{1}}\left(\bar{g}-g^{D}\right)>0
\end{aligned}
$$

From (32)-(34) one can establish that inflation is above its zero target, while output and public spending are below their target levels. Clearly this situation worsens when the real wage target of the trade union increases and when the authorities wish to increase public spending. It is also straightforward to show that for $\mu_{2}=\delta_{2}=0$, output and inflation are at their targets as spending is not an objective for neither authority.

In contrast to the above result the commitment solution is characterized by the following equations (where $\mathrm{C}$ stands for commitment): ${ }^{59}$

$$
\begin{aligned}
& \left(\bar{g}-g^{c}\right)=\frac{\alpha^{2} \delta_{1}(v+\bar{g})}{\left[\alpha^{2} \delta_{1}\left(1+\mu_{2}\right)+\delta_{2}\right]}>0 \\
& y^{c}=-\frac{\delta_{2}}{\alpha \delta_{1}}\left(\bar{g}-g^{c}\right)<0
\end{aligned}
$$

\footnotetext{
${ }^{58}$ Also see Alesina and Tabellini (1987), p. 624.

${ }^{59}$ Note that the commitment solution requires that expected inflation is set equal to actual inflation before taking the central bank's first order condition.
} 
$\pi^{C}=\mu_{2}\left(\bar{g}-g^{C}\right)>0$

A straightforward comparison of (32)-(34) with (35)-(37) immediately establishes that inflation, output and public spending are lower in the commitment regime than in the discretionary regime, while taxes in the commitment regime are higher than in the discretionary regime. A more striking result of the paper is that the commitment regime might make the fiscal as well as the monetary authority worse off than the discretionary regime if $\mu_{\mathrm{i}} \neq \delta_{\mathrm{i}}$. The reason for this result can be summarized as follows. As a committed central bank gives less support to public spending financed via money creation, the fiscal authority has to rely more on distortionary taxes in order to finance public spending. But higher taxes induce output to decrease. Necessarily the government is worse off if the loss in spending and output outweighs the gain from lower inflation. This is likely to be the case if the government places a much higher weight on public spending than the central bank, i.e., $\mu_{2}$ is low relative to $\delta_{2}$. The same is true for the central bank if the benefit from the reduced inflation rate, due to the commitment, is outweighed by the output loss resulting from higher taxes. A necessary condition for this to happen is that the central bank cares sufficiently enough about output, i.e., $\mu_{1}$ is large enough. This is a strong result as it states that tax distortions are not invariant to monetary regime changes.

Nonetheless, a problem of this model can be seen in the fact that it does not analyze the impact of aggregate shocks on the economy, i.e., it is deterministic and not stochastic. Hence an important feature of monetary and fiscal policy, namely to stabilize the economy in the presence of shocks, can not be explained. ${ }^{60}$

Summing up, the model above helps to explain the problem of coordinating monetary and fiscal policies and points out that there might be situations where a committed central bank may result in an Pareto inferior solution, but it does not actually resolve the problem of coordinating policies.

\section{A public debt framework}

The main weakness of the models presented so far was that the government did not have the opportunity to issue public debt. The unemployment inflation trade-off example could therefore not explain how the too expansionary fiscal policy together with a too contractionary monetary policy could be financed. The Alesina and Tabellini (1987) approach on the other hand incorporated a government budget constraint, but one that is binding on a period by period basis, i.e., the possibility of issuing debt was ignored. Tabellini (1986) states:

${ }^{60}$ See Debelle and Fischer (1994) and Beddies (1997 and 1999). 
"The government budget constraint provides a dynamic link between fiscal deficits, the creation of monetary base and the time path of public debt." ${ }^{\text {"6l }}$

As the qualitative results are the same in Tabellini's (1988) two period framework as in the 1986 infinite horizon analysis, I will only focus on the dynamic case for two reasons; First, in contrast to a finite two-period framework, the dynamic model allows us to say something about the optimal time paths of monetary growth and the growth rate of public debt. Second, it indicates the importance and the implications of real interest rates and real economic growth. As before, the analysis focuses on the strategic interaction between fiscal and monetary policies, but now in a dynamic set-up, explicitly including debt and deficits. The basic framework consists of the following ingredients. The monetary authority has quadratic preferences over the time path of money growth (the instrument) and public debt (the state variable) weighted in the usual way. The fiscal authority also has quadratic preferences but over the time path of the fiscal deficit-its instrument--and the state variable debt, weighted accordingly. Finally we have the usual dynamic budget constraint, the law of motion of public debt. The authorities' task is to choose a time path for their own instrument subject to the government budget constraint and subject to some presumptions about the time path of the opponent's instrument. The main findings can be summarized as follows. In the feedback-Nash equilibrium the speed of adjustment towards a steady state value of public debt is lower and the absolute value of public debt is higher than in a cooperative equilibrium. ${ }^{62}$ Symmetric commitments can improve the situation compared to the feedbackNash equilibrium but are still inferior to the cooperative solution concerning steady state value of debt and the speed of adjustment. ${ }^{63}$

An interesting feature the model is the impact of changes in the relative weights that the policymakers attach to their targets. If the government cares less about the evolution of public debt relative to its deficit objective, the burden of meeting the government budget constraint and adjusting public debt placed on the central bank increases (recall that the central bank also cares about debt in Tabellini's model). On the other hand Tabellini (1986) argues that the weight which the central bank places on public debt reflects its independence from the treasury. If the government could choose this weight, it would set it to infinity and hence the central bank's solely task would be to provide enough revenue from money

${ }^{61}$ Tabellini (1986), p. 427

${ }^{62}$ In such an equilibrium the opponent's decision rule, not his future actions are taken as given, which means that each player is taking into account that the own current actions affect the opponent's future actions via their impact on the time path of public debt. Necessarily this means that the players follow a "closed loop" strategy (see e.g., Pindyck (1976), p.241)

${ }^{63}$ With precommitment the authorities take current and future actions of the opponent as given, i.e., the time paths of the instruments are a best response respectively. Following such a strategy is called an open loop strategy. 
creation to finance the government's desired level of the fiscal deficit. In a cooperative setting this would mean that monetary policy needs would be totally neglected.

\section{Links to the discussion of inflation contracts and targets}

Reviewing sections II and III, one immediately recognizes that the literature surveyed there does not specifically take into account fiscal aspects such as debt and deficits into the analysis of monetary policy. On the other hand the models on the interaction of fiscal and monetary policies as surveyed in section IV so far ignore the presence of shocks, affecting the economy, that is, the models are nonstochastic and hence ignore stabilization aspects. An interesting aspect that immediately arises in this context is how one can merge the ideas of these two strands of the literature. Although the next model to be reviewed is also nonstochastic, in that is it does not concentrate on stabilization issues, it nonetheless provides useful insights into fiscal and monetary policy making relating to the contracting approach.

\section{Taxes, inflation, and the Walsh contract}

Huang and Padilla (1995) utilize the Alesina and Tabellini (1987) model to examine how the Walsh contract performs in a public finance model. The government is supposed to optimize by conducting fiscal and monetary policy.

As before the socially optimal policy cannot be time consistent as some surprise inflation allows for higher spending, because for a positive spending target the marginal loss decreases with inflation. As a result, time consistency forces inflation, spending and output to be higher and taxes to be lower than they would be if a credible commitment device existed. If the government imposes a Walsh contract on the central banker this can implement the optimal policy but only if fiscal policy is exogenous, that is, the tax rate is given, which is not surprising. If the government determines fiscal policy endogenously via the tax rate this result no longer holds. Basically one returns to a non-cooperative game. The commitment tax rate is not a best reply of the government to the commitment inflation rate under the contract. The government clearly has an incentive to raise taxes marginally in order to increase spending. Hence this cannot be a Nash equilibrium. Additionally, the commitment inflation rate is no longer a best reply of the central banker. The resulting Nash equilibrium brings about a tax rate, which is higher, and an inflation rate, which is lower than the optimal rates.

\section{Public finances and inflation targets}

In my (1999) paper I consider the implications of the interplay between monetary and fiscal policies in an inflation-targeting framework. In this vein, the paper asks whether an inflation target can induce an independent central bank to provide the optimal rate of inflation, resulting in optimal seigniorage, taxes, public spending, and output and whether this would also lead to optimal stabilization of aggregate supply shocks? The aim of this model is thus to merge the two building blocks discussed earlier to derive implications for the optimal policy 
mix, the optimal policy response to a supply shock, and a way how coordination can actually be achieved. ${ }^{64}$

The analysis is formulated as a game between the private sector, the monetary authority and the fiscal authority. The main results can be summarized as follows. A social planner, when in charge of monetary and fiscal policy, can achieve only a second-best equilibrium as lumpsum taxes are ruled out. ${ }^{65}$ The social planner then has to use alternative sources of finance-distortionary taxes, seigniorage and the shortfall of public expenditure from its desired target. The resulting second-best equilibrium involves optimal positive mean inflation. Therefore, depending on the tax base-that is, the size of real base money holdings-it appears to be optimal to raise seigniorage revenues to some extent, which is in contrast to the various zero inflation rules studied in the literature. Since discretionary policymaking is ruled out, the optimal positive inflation rate derives from optimal revenue considerations and not from a desire to raise output via surprise inflation. Aggregate supply shocks cause inflation, taxes, spending, and output to fluctuate (second best) optimally around their respective means. The policy outcome under the assumption that a benevolent policymaker is in charge of monetary and fiscal policy serves as a benchmark case. Once policies are decentralized, that is, monetary policy is delegated to an independent but committed central bank, both financing and stabilization are distorted. Since the central bank does not optimize subject to the government's budget constraint and therefore ignores the social value of seigniorage, the entire financing requirement has to be met by the fiscal authority. The central bank does not provide any seigniorage revenues, either through budgetary considerations, or through a desire to boost output closer to its target through surprise inflation. Therefore, the fiscal authority has to rely to a greater extent on taxes-causing output to move further away from its desired target - and a larger expenditure gap. In terms of stabilization, this paper finds that inflation/seigniorage fluctuates less, while output and spending vary more. As a result, the social loss in this scenario is larger than under centralization. A way out of this dilemma is to impose a non-state-contingent inflation target on the central bank. The appealing feature of this target is that it provides the optimal level of expected seigniorage. This result highlights that any output effect in the targeting regime derives from lower taxation since the amount of taxes necessary to finance a given financing requirement depends on the level of seigniorage provided by the central bank. The optimal inflation target is allowed to vary, depending on the base for the inflation tax. At the limit, where real base money holdings tend to zero, the seigniorage motive vanishes and the

${ }^{64} \mathrm{~A}$ large body of literature has also focused on the seigniorage hypothesis as part of an optimal taxation problem. See for example Mankiw (1987), Fukuta and Shibata (1994), Froyen and Waud (1995), Gros and Vandille (1995), Evans and Amey (1996), and Click (1998). For an empirical investigation of developing countries, see Ashworth and Evans (1998).

${ }^{65}$ For an analysis with lump-sum taxes in the deterministic case, see Beetsma and Bovenberg (1997a), and, in the stochastic case, Beddies (1997). 
optimal inflation target becomes zero. In terms of society's loss, we show that this solution-in which the central bank is independent but subject to an optimal inflation target-dominates the arrangement in which the independent central bank has no inflation target, but is still inferior to the centralized case.

\section{The monetary policy implications and public debt}

In his (1996) contribution Dornbusch analyzed the policy issues of monetary policy and public debt. As far as this paper is concerned, I will only focus on the credibility issues as they are linked to the time inconsistency problem of sections II and III. To see why a policymaker with a specific target for the growth rate of the real debt ratio might be tempted to engage in surprise inflation consider the following simple debt dynamics equation:

$d=(r-y) b-s$,

where $d$ denotes the rate of increase of public debt as a ratio of GDP, $y$ is the growth rate of the economy, $b$ is the ratio of outstanding public debt over GDP, $r$ is the real interest rate and $s$ denotes the fiscal surplus. Two issues concerning equation (38) are important to note. Firstly, the debt growth ratio decreases if the real interest rate is lower than output growth, as servicing the outstanding debt (the first term in (38)) decreases. This obviously gives the government an incentive to engage in surprise inflation to raise output, if defined as a Lucas type logarithmic surprise supply function. Secondly, a higher fiscal deficit or a lower or negative surplus increases the debt ratio for two reasons: (i) directly, as deficits have to be financed by issuing debt, and (ii) indirectly, as the outstanding public debt increases and therefore the debt service increases. Dornbusch (1996) states:

"Deficit finance with a real interest rate that exceeds the growth rate of output leads to rising debt. Rising debt increases deficits and hence leads to ever increasing debt and debt ratios. " 66

Suppose that the government has the following preferences over the growth rate of the real debt ratio, inflation and the budget surplus. If we think that primary budget surpluses are regarded as negative, a fiscal deficit would enter the following government loss function necessarily with a negative sign. Using Dornbusch's (1996) notation the loss function is given by: ${ }^{67}$

$L=\left[\left(r+\pi^{e}-\pi-y\right) d-s\right]^{2}+a \pi^{2}+c s^{2}$

\footnotetext{
${ }^{66}$ Dornbusch (1996), p. 14.

${ }^{67}$ See Dornbusch (1996), p. $18 \mathrm{ff}$.
} 
where $\mathrm{a}$ is the weight placed on inflation and $\mathrm{c}$ denotes the weight placed on the budget surplus, both relative to the real debt growth target. Assuming that the private sector has rational expectations, i.e., sets $\pi=\pi^{\mathrm{e}}$ and the nominal interest rate is determined by $r+\pi^{\mathrm{e}}$, the resulting Nash equilibrium for inflation and the primary fiscal budget surplus satisfies:

$$
\begin{aligned}
\pi^{*} & =\frac{c}{(1+c) a}(r-y) b^{2} \\
s^{*} & =\frac{(r-y) b}{1+c}
\end{aligned}
$$

Since the public sector is assumed to form rational expectations, surprise inflation cannot reduce the real value of debt, because the public embodies this "government disincentive" in nominal interest rates. Clearly, if the government has a strong preference for deficits, i.e., is averse to running a primary budget surplus as captured by the parameter $c$, inflation tends to be higher. The same is true for higher outstanding debt ratios. This simply means that governments with a bigger debt problem even have a stronger incentive to engage in surprise inflation although it does not help anyone. In contrast, a government caring more about inflation, i.e., placing a higher weight a on inflation, tends to reduce inflation in that Nash equilibrium. Finally, the greater the difference between the real interest rate and the economy's growth rate, the higher will be inflation. The reason is again that the government's incentives to create some surprise inflation are stronger in this case, as fooling the public would help to close this gap between the real interest rate and the growth rate of the economy.

The credibility problem appearing in this set-up is the following. According to Dornbusch (1996):

"...we argue that today inflating away debts no longer works; even so, the present discussion underlines that the mere presence of debts and the resulting temptation is a source of inflation unless credible commitments can be made." 68

As suggested by Dornbusch, one way of getting around this problem would be to denote debt in foreign currency (stable and strong) as restrictive monetary policy so that reducing debt service and hence debt growth would no longer be conflicting objectives. Why? The latter could exactly be achieved by tightening monetary policy because this avoids depreciation of the own currency.

\section{A general equilibrium approach-Monetary Union}

Woodford (1995) uses a general equilibrium model to show that considering the time path of the public debt is an important ingredient in achieving price stability. On theoretical grounds

${ }^{68}$ Dornbusch (1996), p. 19. 
the monetarist view would consider monetary policy as the major determinant of equilibrium prices. Thus any impact of fiscal policy on prices must be due to a change in the institutional arrangement in which monetary and fiscal policies are conducted. While Ricardian equivalence would ensure that prices do not react to changes in the fiscal policy stance because changes in public savings will be offset by changes in private savings, simple demand analysis suggests that any fiscal expansion could be offset by an appropriate monetary contraction. The model proposed by Woodford (1995) shows that fiscal policy may well result in macroeconomic instability and that achieving price stability within a monetary union requires some fiscal discipline. This is true because fiscal imbalances in one country feed through to other countries via changes in the value of the unified currency with the rest of the world. What matters in this framework is the present value of the Union's overall budget. In order to maintain this present value, the expansionary ambitions of one country have to be financed by the other countries. As such, Woodford's (1995) concludes that the fiscal criteria within EMU are a reasonable arrangement.

\section{A detour to EMU}

There are many arguments in favor and against the Maastricht fiscal criteria. Dornbusch (1997) for example argues that the insistence on the Maastricht fiscal criteria are overdone mainly because national debt, say Italian debt, will remain Italian debt after the transition to a single currency. The external debt of Italy is so low that its credit rating (this applies only to dollar debt) is quite high. Even if the Italian debt ratio were to increase and hence its credit risk were to increase, the only thing that would change would be the interest rate spread between Italian bonds and other countries' bonds. Investors would change their portfolio structure leaving the Italian debt problem an Italian one and not one of the union as a whole. Furthermore, the Maastricht treaty provides the European Central Bank (ECB) with independence, meaning that it is neither allowed to accept guidance of any Union government, nor should it finance any Union government. Wyplosz (1997) also has some doubts about the stability pact as it stands. He argues that a proper definition of fiscal policy must involve the idea of sustainability because excessive debt accumulation today might have to be reversed at some time in the future. He also emphasizes the relevance of the 3 percent deficit ratio and the 60 percent debt ratio outlined in the Maastricht treaty. While the 3 percent deficit ratio is thought of as reflecting investment spending of the public sector it entirely ignores expenditures which have to do with human capital accumulation (e.g., education) as an important determinant of economic growth. Furthermore Wyplosz (1997) states:

"The 60 percent debt/GDP rule was chosen because it was the average of EU countries when the Maastricht Treaty was being negotiated, with or with not even the pretense of any deeper economic justification" 69

${ }^{69}$ Wyplosz (1997), p. 13. 
Although the fiscal criteria reflect the desire of the EU countries to insure the ECB's independence they bind their hands in terms of fiscal stabilization's. Together with the loss of monetary control the EMU arrangement might cause serious disruptions at least in some countries especially in the light of a lack of intra European redistribution possibilities. The U.S. currency area for example has a federal government that Europe does not. ${ }^{70}$ McKinnon (1997) on the other hand explores an argument more in favor of the stability pact. Although debt remains a national problem one has to keep in mind that many bonds are in banks, pension funds and other financial institutions. This implies that a debt crisis in one country in EMU might have substantial implications for this particular country and the rest of the union, jeopardizing the ECB's independence. For that reason, McKinnon (1997) argues that ex ante and ex post fiscal discipline is absolutely necessary.

\section{E. Issues for discussion}

The previous sections dealt with the interplay between monetary and fiscal policy when the fiscal and the monetary authority are treated as two independent policy institutions. The question was how non-cooperative strategic behavior of the policymakers determines the outcome in terms of inflation, output and in a public finance environment also in terms of tax rates and spending. The Dornbusch (1996) model differs from this line of research in a way that it does not focus on the interaction of monetary and fiscal policies but on the incentive problem that a government might have when public debt is high.

Comparing the Alesina and Tabellini (1987) approach and its extension by Huang and Padilla (1995) one can readily observe the following relation. In Alesina and Tabellini (1987) the committed central bank supports public spending via money creation to a lesser extent. Thus the fiscal authority has to rely more on distortionary taxes in order to finance public spending. On the other hand higher taxes induce output to decrease. Whether the authorities in charge of monetary and fiscal policy lose from this institutional setting inevitably depends on the weights which the government places on spending and the central bank on output. The key result was that tax distortions are not invariant to monetary regime changes. What Alesina and Tabellini did not clarify is where the commitment of the central bank comes from. Huang and Padilla (1995) got around this issue by merging the Alesina and Tabellini (1987) framework with Walsh's (1995a) idea of a central bank contract. By doing so, the authors could answer the question why and how the central bank should be committed, namely through the Walsh contract.

Nonetheless as mentioned earlier these models do not emphasize how institutional design for central banks (in the public finance environment) affects stabilization of random shocks to the economy. One study, however, deals with the interplay between fiscal and monetary policy in a stochastic set-up. Debelle and Fischer (1994) use the Alesina and Tabellini (1987)

${ }^{70}$ On the issue of optimal currency areas, e.g., U.S. versus Europe see the articles by Kenen (1997), Mundell (1997), and Mussa (1997). 
framework to explore the question of how independent the central bank should be. Their key results are first of all, as in Rogoff (1985), that gaining credibility comes at the cost of loosing flexibility. They specifically stress the importance of fiscal parameters, such as the government's weights on output deviations and the spending deviation from some target. Inflation will depend on these fiscal parameters as long as the central bank cares about output. One point that is worth mentioning in this context is the following. In the Debelle and Fischer (1994) model the central bank and the government have different preferences because the government cares about public spending, while the central bank (as society) is assumed not to care about expenditures. However, one problem then is that the central bank does not internalize the budget constraint of the government (which is assumed to be the same as in the Alesina and Tabellini (1987) framework). The lack of motivating why preferences should be different among agents, could easily be accommodated by not treating government expenditure as a residual, resulting from taxation and seigniorage (as the authors do). Better and also more plausible would be to assume a government which faces a well defined constrained optimization problem where spending is treated as a choice variable rather than a residual. ${ }^{71}$ In a decentralized policy setting it then does not matter whether the central bank cares about public spending as the central bank does not have to make its decisions subject to the government's budget constraint.

\section{Conclusion}

The purpose of this literature survey is to provide an overview over the theoretical grounds of monetary policymaking. Due to the large amount of literature existing in this particular field of interest, the choice of models can be at best a selective one. For a long time, monetary policy making was predominantly looked at from the perspective of potential dynamic inconsistencies, with delegation as the most popular solution to the problem. The second building block of monetary policy analysis on the other hand is its interaction with fiscal policy. The paper attempted to cover these building blocks by first discussing the well-known time inconsistency problem as well as some early suggestions for its solution. It then proceeded to elaborate on an interesting approach toward correcting the monetary authority's incentive to create surprise inflation, namely by either imposing a linear inflation contract or a suitable chosen inflation target. An especially important feature of monetary policy, namely that its instruments operate within long lags showed that the Walsh contract may not be appropriate. The inflation target as a means of removing a potential inflationary bias on the other hand is lacking practical relevance, given that it had to be smaller than the socially optimal inflation rate or even negative.

In looking at the second building block the paper dealt partly with the large body of literature, focusing specifically on the interaction between monetary and fiscal policies both with respect to the often-discussed Phillips trade-off and in a public finance setting. These models mainly have to do with the problem of coordinating monetary and fiscal policies and

${ }^{71}$ See Beddies (1997 and 1999), and Beetsma and Bovenberg (1998a and 1998b). 
less so with the question of how fiscal and monetary authorities can cooperate. While the literature provides extensive background for each of these building blocks, less effort has been made in actually linking them - thus looking at the stabilization potential of monetary policy, its credibility and its role as a source of government finance at the same time. In that regard an optimal inflation target can partly resolve the shortcomings of decentralized monetary and fiscal policy interaction and deliver the optimal policy mix for the deterministic part of the inflation, output and spending outcome. Welfare maximizing stabilization efforts could only be achieved by implementing a fully state contingent inflation target, which is not practicable and even less transparent. However, that still does not provide a true model of cooperative policy making. As a result, more work should be done in the area of determining the desirable degree of independence and in the area of fiscal and monetary policy interaction, taking account of stabilization issues within newer frameworks such as inflation targeting.

Since Europe entered into monetary union at the beginning of last year, it would be interesting to construct models that combine the monetary theory of optimal currency areas with issues of fiscal policy. The inflation target and public finances model for example could be extended to allow for fiscal policy interactions between sovereign fiscal authorities within the union, which together interact with the centralized monetary authority, the ECB. Thus, one could focus on the public good character of fiscal policy. Since the European Community lacks a powerful federal government, one could investigate a situation in which the decentralized fiscal authorities can build coalitions to minimize the spillover effects of their fiscal decisions into other union countries. A recent paper by Casella for example constitutes an interesting approach in that direction in that it borrows from the environmental literature by suggesting the creation of a market for deficit permits. 


\section{Bibliography}

and R. Gatti, 1995, "Independent Central Banks: Low Inflation at No Cost?" American Economic Review, Papers and Proceedings 85, 2, pp. 196-200.

Alesina, A., and V. Grilli, 1992, "The European Central Bank." Reshaping Monetary Politics in Europe," in M. Canzoneri, V. Grilli and P. Masson (eds.), Establishing a Central Bank: Issues in Europe and Lessons from the U.S. Cambridge University Press.

Alesina, A., and L.H. Summers, 1993, "Central Bank Independence and Macroeconomic Performance: Some Comparative Evidence," Journal of Money, Credit and Banking 25,2 , pp. $151-162$.

Alesina, A., and G. Tabellini, 1987, "Rules and Discretion with Noncoordinated Monetary and Fiscal Policies," Economic Inquiry 25, pp. 619-630.

Andersen, T. M., and F. Schneider, 1986, "Coordination of Fiscal and Monetary Policy under Different Institutional Arrangements," European Journal of Political Economy 2, 2, pp. 169-91.

Ashworth, J., and L. Evans, 1998, "Seigniorage and Tax Smoothing in Developing Countries," Journal of Economic Studies, Vol. 25 (No. 6), pp. 486-95.

Backus, D., and J. Driffill, 1985, "Inflation and Reputation," American Economic Review 75, 3 , pp. $530-538$.

Baker, G. P., 1992, "Incentive Contracts and Performance Measurement," Journal of Political Economy 100, 3, pp. 598-613.

Barro, R. J. 1986, "Reputation in a Model of Monetary Policy with Incomplete Information," Journal of Monetary Economics 17, pp. 1-20. , and D.B. Gordon, 1983a, "A Positive Theory of Monetary Policy in a Natural Rate Model," Journal of Political Economy 91, p 589-610. 1983b, "Rules, Discretion and Reputation in a Model of Monetary Policy," Journal of Monetary Economics 12, pp. 101-120.

Beddies, C. H., 1999, "Monetary Policy and Public Finances: Inflation Targets in a New Perspective", IMF Staff Papers Vol. 46, No. 3 (Fall), pp. 293-314. , 1997, "The Interaction of Fiscal and Monetary Policies in a World with Uncertainty," Queen Mary and Westfield College Discussion Paper No. 372. 
Beetsma, R. M., and A. L. Bovenberg, 1997a, "Designing Fiscal and Monetary Institutions in a Second-Best World," European Journal of Political Economy, Vol. 13 (February), pp. 53-79.

1997b, "Central Bank Independence and Public Debt Policy," Journal of Economic Dynamics and Control 21, pp. 873-894.

, 1998, "Monetary Union Without Fiscal Coordination May Discipline Policymakers," Journal of International Economics, Vol. 45 (August), pp. 239-58.

, 1999, "The Interaction of Fiscal and Monetary Policy in a Monetary Union: Balancing Credibility and Flexibility," in The Economics of Globalization: Policy Perspectives from Public Economics, ed. by Assaf Razin and Efraim Sadka (Cambridge: Cambridge University Press).

Beetsma, R. M., and H. Jensen, 1997, "Inflation Targets and Contracts with Uncertain Central Banker Preferences," CEPR Discussion Paper No. 1562.

Berger, H., J. de Haan, and S. W. C. Eijffinger, 2000, "Central Bank Independence: An Update of the Theory and Evidence," CEPR Discussion Paper No. 2353.

Bernanke, B. S., and F. S. Mishkin, 1997, "Inflation Targeting: A New Framework for Monetary Policy?" Journal of Economic Perspectives 11, 2, pp. 97-116.

Blinder, A. S., "What Central Bankers Could Learn from Academics and Vice Versa," Journal of Economic Perspectives 11, 2, pp. 3-19.

Briault, C., A. G. Haldane, and M. King, 1995, "Independence and Accountability," Mimeo, Bank of England.

Canzoneri, M. B., 1985, "Monetary Policy Games and the Role of Private Information." American Economic Review 75, 5, pp. 1056-1070.

C. Nolan, and A. Yates, 1995, "Mechanisms for Achieving Monetary Stability: Inflation Targeting Versus the ERM," forthcoming in Journal of Money Credit and Banking.

Casella, A., 1999, "Tradable deficit permits: efficient implementation of the Stability Pact in the European monetary Union," Economic Policy: A European Forum, (U.K.); No. 29 (October), pp. 323-61.

Cripps, M. W., 1995, "Rules, Reputation and Macroeconomic Policy Co-ordination," Journal of Economic Dynamics and Control 20, 1996, pp. 521-523. 
Cukierman, A., 1992, Central Bank Strategy, Credibility and Independence: Theory and Evidence, MIT Press.

1995, "Towards a Systematic Comparison Between Inflation Targets and Monetary Targets," in L. Leiderman and L. E. O. Svensson (eds.), Inflation Targets. London, CEPR.

P. Kalaitzidakis, L. H. Summers, and S. B. Web, 1993, "Central Bank Independence, Growth, Investment and Real Rates," Carnegie-Rochester Conference Series on Public Policy 39, pp. 95-140.

Currie, D. A., and P. Levine, 1993, Rules, Reputation and Macroeconomic Policy Coordination, Cambridge, U.K., Cambridge University Press. , and J. Pearlman, 1996, "The Choice of Conservative Bankers in Open Economies: Monetary Regime Options for Europe," Economic Journal 106, 435, pp. 345-358.

Debelle, G., and S. Fischer, 1994, "How Independent Should a Central Bank Be?" in J. C. Fuhrer (ed.), Goals, Guidelines and Constraints Facing Monetary Policymakers. Boston, MA, Federal Reserve Bank of Boston, pp. 195-221.

Dornbusch, R., 1996, "Debt and Monetary Policy: The Policy Issues." NBER Working Paper No. 5573.

Driffill, J., 1989, "Macroeconomic Policy Games with Incomplete Information: Some Extensions," in F. van der Ploeg and A. J. de Zeeuw (ed.), Dynamic Policy Games in Economics. Elsevier Science Publishers B.V. (North Holland), pp. 289-322.

Eijffinger, S. C. W. and J. de Haan, 1996, "The Political Economy of Central Bank Independence," Special Papers in International Economics 19, pp. 1-77.

Evans, J. L., and M. C. Amey, 1996, "Seigniorage and Tax Smoothing - Testing the Extended Tax Smoothing Model," Journal of Macroeconomics 18, 1, pp. 111-125.

Favero, C. A., and F. Spinelli, 1996, "Deficits, Money Growth and Inflation in Italy," Mimeo, Universita L Bocconi and Universita di Brescia.

Fischer, S., 1995, "Central Bank Independence Revisited," American Economic Review, Papers and Proceedings 85, 2, pp. 201-206.

Flood, R. P., and P. Israd, 1989, "Monetary Policy Strategies," International Monetary Fund Staff Papers 36, 3, pp. 612-632.

Friedman, J., 1971, "A Noncooperative Equilibrium for Supergames," Review of Economic Studies 8, pp. 1-12 
1977, Oligopoly and the Theory of Games. Amsterdam, North Holland.

Friedman, J. W., 1991, Gametheory with Applications to Economics, Second Edition, New York.

Friedman, M., 1956, Studies in the Quantity Theory of Money, University of Chicago Press. , 1962, "Should There Be an Independent Authority?" in L. Yeager (ed.), In Search of a Monetary Constitution. Harvard University Press, pp. 219-243.

, and A. Schwartz, 1963, A Monetary History of the United States, 1867-1960, Princeton University Press for the National Bureau of Economic Research.

Froyen, R. T., and R. N. Waud, 1995, "Optimal Seigniorage versus Interest-Rate Smoothing," Journal of Macroeconomics 17, 1, pp. 111-129.

Fukuta, Y., and A. Shibata, 1994, "A Cointegration Test of the Optimal Seigniorage Model," Economics Letters 44, 4, pp. 433-437.

Goodhart, C. A. E., 1993a, "ERM and EMU," LSE Financial Markets Group, Special Paper Series No. 58. , 1993b, "Central Bank Independence," LSE Financial Markets Group, Special Paper Series No. 57. , and H. Huang, 1995, "What is the Central Bank's Game," LSE Financial Markets Group Discussion Paper No. 222.

Gros, D., and G. Vandille, 1995, "Seigniorage and EMU: The Fiscal Implications of Price Stability and Financial Market Integration," Journal of Common Market Studies 33, 2 pp. 175-196.

Haldane, A. G. (ed.), 1995, Targeting Inflation: A Conference of Central Banks on the Use of Inflation Targets. Organized by the Bank of England, 9-10 March.

Herrendorf, B., 1996, "Why Inflation Targeting May Partly Substitute for Explicit Precommitment," University of Warwick Discussion Paper No. 451. , and B. Lockwood, 1996, "Rogoff"s Conservative Central Banker Restored," University of Warwick Discussion Paper No. 450.

Huang, H., and J. Padilla, 1995, "Fiscal Policy and the Sub-Optimality of the Walsh Contract for Central Bankers," LSE Financial Markets Group Discussion Paper No. 223.

Jensen, H., 1994, "Loss of Monetary Discretion in a Simple Dynamic Policy Game," Journal of Economic Dynamics and Control 18, pp. 763-779. 
, 1997, "Credibility of Optimal Monetary Delegation," American Economic Review 87, 5 , pp. 911-920.

Joines, D., 1985, "Deficits and Money Growth in the United States," Journal of Monetary Economics 16, pp. 329-351.

Kenen, P. B., 1997, "Preferences, Domains, and Sustainability," American Economic Review, Papers and Proceedings 87, 2, pp. 211-213.

Kreps, D., and R. Wilson, 1982, "Reputation and Imperfect Information." Journal of Economic Theory 27, pp. 253-279.

Kydland, F. E., and E. C. Prescott, 1977, "Rules Rather than Discretion: The Inconsistency of Optimal Plans," Journal of Political Economy 85, 3, pp. 473-493.

Laurens, B. and E. G. de la Piedra, 1998, "Coordination of monetary and fiscal Policies", IMF Working Paper 98/25, (Washington: International Monetary Fund).

Leiderman, L., and L. E. O. Svensson, eds., 1995, Inflation Targets. London, CEPR.

Lohmann, S., 1992, "The Optimal Degree of Commitment: Credibility versus Flexibility," American Economic Review 82, 1, pp. 273-286.

Mankiw, G. N., 1987, "The Optimal Collection of Seigniorage: Theory and Evidence," Journal of Monetary economics 20, pp. 327-341. ed., 1994, Monetary Policy, Chicago, University of Chicago Press.

McCallum, B. T., 1996, “Crucial Issues Concerning Central Bank Independence,” NBER Working Paper No. 5597. 1997, "Crucial Issues Concerning Central Bank Independence," Journal of Monetary Economics 39, pp. 99-112. , 1995, "Two Fallacies Concerning Central Bank Independence," American Economic Review, Papers and Proceedings 85, 2, pp. 207-211.

McKinnon, R. I., 1997, "EMU as a Device for Collective Fiscal Retrenchment," American Economic Review, Papers and Proceedings 87, 2, pp. 227-229.

Milgrom, P., and J. Roberts, 1982, "Predation, Reputation and Entry Deterrence," Journal of Economic Theory 27, pp. 280-312.

Mundell, R. A., 1997, "Currency Areas, Common Currencies, and EMU," American Economic Review, Papers and Proceedings 87, 2, pp. 214-216. 
Mussa, M., 1997, "Political and Institutional Commitment to a Common Currency," American Economic Review, Papers and Proceedings 87, 2, pp. 217-220.

Nowaihi, Ali al, and P. Levine, 1994, "Can Reputation Resolve the Credibility Problem?" Journal of Monetary Economics 33, 1, pp. 355-380. , 1996, "Independent but Accountable: Walsh Contracts and the Credibility Problem," ESRC Working Paper No. 11.

, 1993, "Designing Institutions for Monetary Stability," Carnegie-Rochester Conference Series on Public Policy 39, pp. 53-89.

, 1994a, Monetary and Fiscal Policy. Volume 1, Credibility, MIT Press.

, 1994b, Monetary and Fiscal Policy. Volume 2, Politics, MIT Press.

, 1996, "Monetary Cohabitation in Europe," American Economic Review, Papers and Proceedings 86, 2, pp. 111-116.

Pindyck, R. S., 1976, "The Cost of Conflicting Objectives in Policy Formulation," Annals of Economic and Social Measurement 5, 2, pp. 239-248.

Rankin, N., 1998, "Is Delegating Half of Demand Management Sensible?" International Review of Applied Economics, Vol. 12 (September), pp. 415-22.

Rogoff, K., 1985, "The Optimal Degree of Commitment to a Monetary Target," Quarterly Journal of Economics 100, pp. 1169-1190.

, 1987, "Reputational Constraints on Monetary Policy," Carnegie Rochester Conference Series on Public Policy 26, pp. 141-190. , and N. Wallace, 1981, "Some Unpleasant Monetarist Arithmetic," Federal Reserve Bank of Minneapolis, Quarterly Review, pp. 1-17.

Selten, R., 1978, "The Chain-Store Paradox," Theory and Decision 9, pp. 127-159.

Svensson, L. E. O., 1995, "Optimal Inflation Targets, Conservative Central Banks, and Linear Inflation Contracts," CEPR Discussion Paper No. 1249. 1997, "Optimal Inflation Targets, Conservative Central Banks, and Linear Inflation Contracts," American Economic Review 87, 1, pp. 98-114.

Tabellini, G., 1986, "Money, Debt and Deficit in a Dynamic Game," Journal of Economic Dynamics and Control 10, pp. 427-442. 
1988, "Monetary and Fiscal Policy Co-ordination with a high Public Debt," in F. Giavazzi, and L. Spaventa (eds.), High Public Debt: The Italian Experience. Cambridge University Press, pp. 90-134.

Taylor, J. B., 1993, "Discretion versus Policy Rules in Practice," Carnegie-Rochester Conference Series on Public Policy 39, pp. 195-214.

Thompson, E., 1981, "Who Should Control the Money Supply," American Economic Review, Papers and Proceedings 71, 2, pp. 356-361.

Vickers, J., 1986, "Signaling in a Model of Monetary Policy with Incomplete Information," Oxford Economic Papers 38, pp. 443-455.

Waller, C. J., 1992, "The Choice of a Conservative Central Banker in a Multisector Economy," American Economic Review 82, 4, pp. 1006-1012. 1995, "Performance Contracts for Central Bankers," Review Federal Reserve Bank of St Louis, pp. 3-14. 1996, "Central Bank Independence, Economic Behaviour and Optimal Term Lengths," American Economic Review 86, 5 pp. 1139-1153. 1995a, "Optimal Contracts for Central Bankers," American Economic Review 85, 1, pp. $150-167$. , 1995b, “Is New Zealand's Reserve Bank Act of 1989 an Optimal Central Bank Contract?" Journal of Money, Credit and Banking 27, 4, pp. 1179-1191.

Woodford, M., 1996, "Control of the Public Debt: A Requirement for Price Stability," CEPR European Summer Symposium in Macroeconomics hosted by the Banco di Espagna.

Wyplosz, C., 1997, “EMU: Why and How It Might Happen,” Journal of Economic Perspectives 11, 4, pp. 3-21. 